\title{
Başlangıçtan Yirminci Yüzyılın İlk Yarısına Kadar İslâmî Yazımda Cihad Literatürü*
}

\author{
Jihad Literature in Islamic Writing from the Beginning to the First Half of the \\ Twentieth Century
}

Mehmet ÇOBAN ${ }^{* *}$

Öz

Abstract

Cihadın mana, boyut ve uygulamasına bakıldığında Considering the meaning, dimension, and application of genel olarak Allah yolunda can ve mal ile mücadele jihad it can be generally defined as struggling with life etmek şeklinde tanımı yapılabilir. Cihad, Kur'an ve and property in the way of Allah. Jihad is one of the main sünnetin üzerinde önemle durduğu temel meselelerden issues that the Qur'an and Sunnah put emphasis on. biridir. Hem teorik hem de pratik bir mesele olan cihad Many studies have been conducted from the first period konusu ile ilgili ilk dönemden günümüze kadar pek çok to the present day and rich literature has been created çalışma yapılmış olup zengin bir literatür oluşturulmuştur. on the subject of jihad, which is both a theoretical and $\mathrm{Bu}$ araștırmada, ilk asırlardan yirminci yüzyllın ilk practical issue. In this research, the written literature on yarısına kadar söz konusu alanla ilgili yazılan literatür ele the field from the first centuries to the first half of the alınacaktır. Mevcut akademik çalışmalarda genel olarak twentieth century will be discussed. In the current hadis ilmi özelinde Kitâbü'--cihad edebiyatı ve belli academic studies generally, Kitab al-jihad literature in the dönemlerde yazllan cihad risaleleri incelenir. Bu science of hadith and written jihad treatises in certain çalışmada ise İslâm hükümlerinin mükellefler üzerindeki periods are examined. In this study, how the subject of yansımasını konu edinen fıkı ilminde cihad konusunun jihad is handled in the science of figh, which deals with nasıl ele alındığı, fıkıh mezhepleri arasında bu yazım the reflection of Islamic provisions on taxpayers, which alanında hangi mezhebin daha ağırlıkta olduğu, cihad sect is more dominant in this writing area among the figh yazımının tarih boyunca hangi yüzylllarda ve sects, in which centuries and centers the writing of jihad merkezlerde yoğunlaștığı hususları araştırlacaktır. has been concentrated throughout history, etc. issues Bununla birlikte yirminci yüzylın ilk yarısına kadar risale will be explored. In addition to this, a breakdown of the ve kitap olarak kaleme alınan cihad literatürünün bir jihad literature, which was written as a treatise and book bütün olarak dökümü ortaya konulacaktır. until the first half of the twentieth century, will be revealed as a whole.

Anahtar Kelimeler: İslâm Hukuku, Cihad, Literatür, Keywords: Islamic Law, Jihad, Literatüre, Fiqh Sects, Fıkhî Mezhepler, İslâmî Yazım. İslamic Writing.

\section{Giriş}

İnanç, hukuk ve ahlaka dair ilke ve kurallardan oluşan bir değerler ve eylemler alanına sahip İslâm dini, söz konusu alanlardaki ilke ve gayeleri bütün insanlara ulaştırmayı amaçlamaktadır. $\mathrm{Bu}$ hedefi gerçekleştirme yolundaki en önemli enstrümanlarından birisi hiç şüphesiz cihaddır. Nitekim cihad olgusu, gerek Müslümanların diğer toplumlarla olan savaş münasebetlerinde gerekse de bir din olarak İslâm'ın dünyaya hâkim kılınmasında merkezi bir öneme sahip olmuştur. Bu itibarla cihad, mükellef olarak Müslümanın bütün hayatını düzene sokmayı kendisine konu

Geliş Tarihi: 15.10.2021, Kabul Tarihi: 19.12.2021. Bu makale, yazarın "İslâm Hukukunda Cihad Literatürü ve Bedreddin İbn Cemâa’nın Cihadla İlgili Eserlerinin Değerlendirilmesi” adlı yüksek lisans tezinden yararlanılarak oluşturulmuştur.

*** Arş. Gör., Bitlis Eren Üniversitesi, İslami İlimler Fakültesi, İslam Hukuku Anabilim Dalı, mehmedim73@windowslive.com, ORCID: 0000-0002-4827-4751. 
edinen fikıh ilminin içinde incelenmiş, şerî ve hukukî boyutları bir bütün olarak araştırılmıştır. Bundan ötürü cihadın hukukî ve dinî boyutuna 1şık tutmak amacıyla oldukça erken sayılabilecek bir dönemde müstakil eserler telif edilerek günümüze kadar zengin bir literatür meydana gelmiştir. Aynı zamanda cihad konusu, fikhın tedvin edildiği ilk dönemlerden itibaren Kitâbü'l-cihad ve Kitâbü's-siyer başlıkları altında etraflıca incelenmiştir. Bununla birlikte İslâm yazım edebiyatının birçok alanında da cihadla ilgili çalışmalara rastlanılmaktadır. İslâm hukuk kurallarına kaynaklık teşkil etmesi itibari ile siyer ve megâzî eserleri cihada dair ilk bilgileri mündemiç mahiyete olanlarıdır. Konunun müstakil olarak ele alındığı eserler ise hicri II. yüzyılın ortalarından itibaren gün yüzüne çıkmaya başlar. Bunlardan ilki cihadın faziletine dair Abdullah b. Mübârek'in (ö. 181/797) Kitâbü'l-cihâd adlı hadis derlemesi eseridir. Akabinde, Davud ez-Zâhirî (ö. 270/884), İbn Ebî’d-Dünyâ (ö. 281/894), Ebûbekir b. Âsım (ö. 287/900), Kummî (ö. 290/903) ile Ebû İshâk İbrahim b. Hammâd'ın (ö. 320/932) aynı adı taşıyan eserleri gelmektedir. Müteakip süreçte cihada dair müstakil çalışmalar artarak devam etmiş ve neticede söz konusu telifat İslâmî literatürde önemli bir yekûn oluşturmuştur.

$\mathrm{Bu}$ araştırmanın temel amacı, cihadın klasik fıkıh kaynaklarında hangi başlıklar altında ve nasıl incelendiğini ortaya koymak, cihad alanında yapılan çalışmaların genel bir dökümünü vermek, İslâmî literatürde cihadın yoğunlaştığı yüzyılların, bölgelerin ve fıkıh mezhepleri arasında cihad yazımındaki dağılımın haritasını ortaya çıkartmaktır.

$\mathrm{Bu}$ amaçlar doğrultusunda ilk olarak, cihad kelimesinin kavram çerçevesi belirlenecek, akabinde cihadın fürû fıkıh kaynaklarında nasıl bir tasnif ve başlıklandırma dâhilinde incelendiği üzerinde durulacaktır. Daha sonra her mezhepten temsil gücü yüksek iki eser seçilerek cihadın konu edindiği bölümlerin içindekiler listesi tablo halinde sunulacaktır. Bununla klasik füru fıkıh kaynaklarının tasnif, tertib ve tebvîbinde cihadın konumunun ortaya konulması hedeflenecektir. Daha sonra söz konusu literatür “klasik” ve “modern dönem: sömürgecilik sonrası” şeklinde iki ana esas çerçevesinde ve her biri "kitaplar” ve “risaleler” alt başlıklarıyla ele alınacaktır. 
Son olarak dökümü yapılan literatürün yüzyıllar, bölgeler ve mezheplere göre dağılımını gösteren grafikler sunularak cihad yazımının somut verileri ortaya konulacaktır.

Çalışmanın hacminin el vermemesi ve söz konusu literatürdeki çoğu eserin müstakil araştırmaları gerektiren kapsam ve öneme sahip olmasından ötürü literatürde yer alan her eser hakkında detaylı bilgi verme yoluna gidilmeyecek, sadece eserlerin künye ve neşir bilgilerine, yazma nüshalarının bulunduğu kütüphanelere ve yer yer Türkiye'de ilgili eser yahut müellif hakkında yapılan bazı çalışmalara işaret edilmekle yetinilecektir.

Çalışmada, fürû fıkıh kaynaklarında cihad meselesinin işlendiği kısımda mezheplerin temel fıkıh eserlerinden; literatür tespitinde Kâtip Çelebi (ö. 1067/1657), Bağdatlı İsmail Paşa (ö. 1920), Bursalı Mehmed Tahîr (ö. 1925) ve Ömer Rıza Kehhâle (ö. 1987) gibi müelliflerin biyobibliyografik eserlerinden, kataloglardan, cihad alanında yapılan müstakil çalışmalardan ve bu çalışmaların kaynakça bölümlerinden; yazma eserleri tespit için Yazma Eserler Kurumu, İSAM ve muhtelif yazma kütüphanelerinin veritabanlarından istifade edilmiştir. Ayrıca söz konusu alanla ilgili genel taramalar yapılmıştır.

\section{Cihad: Sözlük ve Terim Anlamları Çerçevesinde Anlam Dairesi}

Kendi içinde fürû ve usûl olarak iki kısma ayrılan fıkıh ilmi, İslâm ilim ve düşünce geleneğinin demirbaş disiplinlerinden biri hüviyetinde olup, mükellef olarak Müslüman bireyin amelini konu edinmektedir. Cihad ahkâmı genel olarak bu ilmin fürû kısmında incelenmektedir. Dinî vasatta çok geniş bir anlam yelpazesine sahip olan cihad kavramı bu makalede fıkhî boyutu açısından ele alınacaktır. Fürû fıkıh kaynaklarında cihadın konumuna geçmeden önce bu kavramın lügat ve ıstılahî anlamlarına değinilecek, ardından âyet ve hadislerdeki konumuna işaret edilecektir.

Cihad Arapça'da, "meşakkat, bir işin üstesinden gelmek için bütün imkânları kullanmak, gayret ve güç sarf etmek" manalarına gelen "cühd" ve "cehd” köklerinden 
türemiş bir kavramdır. ${ }^{1}$ Örneğin, " جَهَدَ دابته "hayvanına taşıyabileceğinden fazla yük yükledi”; " جَهَََ الرجل " جَهَنتُ اللبنَ " adam tüm gücüyle mücadele ettiön tüm yağını çıkarttım; " جَهَادنُ الطعـامَ iştahla yemek yedim/çok yemek yedim" kullanımları bu durumu destekler niteliktedir. ${ }^{2}$ Halil b. Ahmed (ö. 175/791) bu kökler arasındaki fark1 cühd, bir iş yapmak için gösterilen en ufak çaba (gayret/takat); cehd, bir işi yapmak için tüm imkânların seferber edilmesi şeklinde izah eder. ${ }^{3}$ Köklerin bu anlam farklılığına

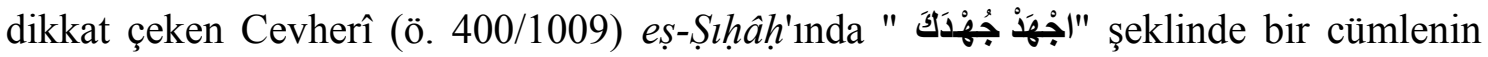

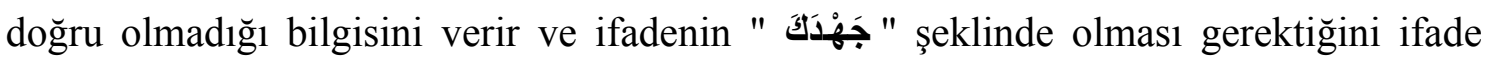
eder. ${ }^{4}$ Cihad kelimesinin mastar olduğunu ifade eden el-Mugrrib sahibi Mutarrizî (ö. 610/1213) cihad için "kişinin arkadaşını korumak için bütün gayret ve gücünü sarf etmesi" şeklinde bir tanıma başvurmaktadır. Cihadın "cehd" mastarıyla "meşakkat", "cühd" mastarıyla "takat" anlamına geldiğini belirten Feyyumî (ö. 770/1368-69) ise kelimenin, "Kişinin talep ettiği şeyi gerçekleştirmek, istediği şeye ulaşmak için güç ve gayret sarf etmek, istediğinde 1srarlı olmak, eziyet ve sıkıntı çekmek" gibi manalara geldiğini söylemektedir. ${ }^{6}$

Cihad kavramının terim anlamına baktığımızda ise birçok âlim tarafından muhtelif tanımların yapıldığı görülmüştür. Örneğin Râgıb el-İsfâhânî (ö. V/XI yüzyılın ilk çeyreği) cihad1, "El ve dil ile düşmana karşı müdafaada gayret sarf etmektir" şeklinde tanımlamış; nefisle, şeytanla ve zahir düşmanla savaş şeklinde bir ayırıma giderek cihadın tasavvufî literatürdeki kullanımını öne çıkarmıştır. ${ }^{7}$ Hanefî fakihi

1 Ebû'l-Ḳāsım Hüseyn b. Muhammed b. er-Râgıb el-İsfahânî, el-Müfredât fì ġarîbi'l-Kur'ân, thk. Șafvân 'Adnan ed-Dâvûdî (Dımaşk: Daru'l-Kalem-Daru'ş-Şâmiyye, 1412), “chd”, 208; Ebü’t-Tâhir Mecdüddîn Muhammed b. Ya'kūb b. Muhammed el-Firûzâbâdî, el-Kāmûsü'l-muhît, thk. Mekteb Tahkiki’t-Turâs fi Müeseseti'r-Risâle (Beyrut: Müessesetü'r-Risâle, 1426), “chd”, 275.

2 Ebû Nasr İsmâîl b. Hammâd el-Cevherî, eṣ-Ṣıhâhh fi'l-lugia, thk. Ahmed Abdulgafûr Attâr Attâr (Beyrut: Dâru'l-‘İlm lil Melâyîn, 1407), "chd”, 2/460-461.

3 Halîl b. Ahmed el-Ferâhîdî, Kitâbu'l-'ayn, thk. Mehdî el-Mahzûmî - İbrâhîm el-Sâmirâî (b.y.: Mektebetü'l-Hilâl, ts.), "chd", 3/386.

4 Cevherî, eș-Ṣlhâhh, "chd", 2/460.

5 Ebü'l-Feth Burhânüddîn Nâsır b. Abdisseyyid b. Alî el-Mutarrizî, el-Muǵgrib fì tertîbi'l-Mu'rib (b.y.: Dâru'l-Kitâbi'l-‘Arebî, ts.), “chd”, 96-97.

6 Ebü'l-Abbâs Hatîbüddehşe Ahmed b. Muhammed b. Alî el-Feyyûmî, el-Miṣbâhu'l-münîr fí garîbi'şşerhi'l-kebîr li'r-Râfi 'î (Beyrut: Mektebetü'l-İlmiye, ts.), "chd”, 1/112.

7 Râgıb el-İsfahânî, el-Müfredât, "chd”, 208. Ayrıca bk. Zeynüddîn Muhammed Abdürraûf b. Tâcil'ârifîn b. Nûriddîn Alî el-Munâvî, et-Tâvkîf 'alâ muhîmâtî't-te'ârîf (Kahire: Alemü'l-Kütüb, 1410), "chd", 113. 
Semerkandî (ö. 539/1144) cihadı, "Hak olan dine davet ve bu daveti kabul etmeyenlerle mal ve nefissle savaşmak" olarak tanımlamıştır. ${ }^{8}$ Aynı kavramı İbn Manzûr (ö. 711/1311) “Düşmanla savaşta gerek dil gerek kuvvet olarak sahip olunan bütün imkânları sonuna kadar kullanmak"9; Kâsânî, "Allah yolunda can, mal, dil ve daha başka şeylerle savaşmada bütün güç ve tâkâti harcamak" "10; Mâlikî fakihi İbn Arafe (ö. 803/1401) ise, “i'lâ-1 kelimetullah için kâfirlerle savaşmak"11 şeklinde tanımlamıştır.

Kur'an'1 Kerim'e baktığımızda cihad kelimesinin kökü ve bu kökten türeyen kelimelerin farklı türevde, pek çok ayette geçtiği görülmektedir. İki yerde ism-i fâil, dört yerde isim, yirmi dört yerde ise fiil şeklinde yer almaktadır. ${ }^{12}$ Muhtelif anlamlara gelen bu kullanımlar bir kısım ayette “Allah'ın rızasına uygun yaşamak için gayret sarf etme" ${ }^{" 13}$ manasına gelmekte iken diğer bir kısmı ise doğrudan savaş ${ }^{14}$ anlamını ifade etmektedir. $^{15}$

Kur'an'1 Kerim'den sonra İslâm dininin en önemli ikinci kaynağı olan sünnet de cihad meselesi üzerinde bilhassa durmaktadır. Söz konusu durumu günümüze ulaşan ve cihadın hükmü, fazileti, keyfiyeti, gayesi ve sonuçları hakkında etraflıca bilgi veren cihadla ilgili rivayetlerde görmek mümkündür. Bu rivayetler -cihadla ilgili yazılmış müstakil eserleri bir tarafa bırakırsak- hadis literatüründe genel olarak Fezâilü'l-cihâd ve Kitâbü'l-cihâd başlıkları altında ele alınmaktadır. ${ }^{16}$

8 Ebûbekir Alâüddîn Muhammed b. Ahmed es-Semerkandî, Tuhfetu'l-fukahā (Beyrut: Dâru'l-Kütübi'l'İlmiyye, 1414), 3/293.

9 Ebü’l-Fazl Cemâlüddîn Muhammed b. Mükerrem b. Alî İbn Manzûr (Beyrut: Daru Sadr, 1414), "Lisânü’l-'Arab”, “chd”, 3/135.

10 Alâüddîn Ebû Bekr b. Mes'ûd b. Ahmed el-Kâsânî, Bedâ'i 'u’s-ṣanâ'i fì tertibi’ş-şerâ'i (Beyrut: Dâru'l-Kütübi'l-'İlmiyye, 1406), 7/97.

11 Ebû Abdillâh Muhammed b. Muhammed b. Muhammed b. Arafe el-Vergammî et-Tûnisî İbn Arafe, el-Muhtașar fi'l-fikhh, thk. Hâfiz Abdurrahman Muhammed Hâyr (b.y.: Müesessetü Hâlf Ahmed elHâbtûr li'l- A'mâli'l-Hayriyye, 1435), 3/5.

12 Muhammed Fuâd Abdülbâkî, el-Mu 'cemü'l-müfehres li-elfâzi'l-Kur'âni'l-Kerîm (Kahire: Daru'l Kütübi'l Misriyye, 1364), “chd”, 182-183.

13 Bk. el-Furkân 25/52; el-Ankebût 29/6.

14 Bk. et-Tevbe 9/41, 48, 81, 86.

15 Ahmet Özel, "Cihad”, Türkiye Diyanet Vakfı İslâm Ansiklopedisi (İstanbul: TDV Yayınları, 1993), $7 / 527$.

16 Cihaddan sayılan ve cihadın farklı tezahürleri ve türleri olarak kabul edilen birçok rivayet için bk. Mehmet Çoban, İslâm Hukukunda Cihad Literatürü ve Bedreddin İbn Cemâa'nın Cihadla İlgili Eserlerinin Değerlendirilmesi (İstanbul: Marmara Üniversitesi, Sosyal Bilimler Enstitüsü, Yüksek Lisans Tezi, 2020), 12-13. 
Kur'an'1-Kerim ve hadislere bakıldığında cihad kavramının gerek doğrudan savaş anlamına gelecek gerekse de Allah rızasına uygun bir yaşam için kişinin elinden gelen bütün imkân ve gayreti göstermesi şeklinde ifade edilebilecek bir kullanım vasatına sahip olduğu görülmektedir. Zira her iki anlamı da ifade edecek birçok ayet ve hadis bulunmaktadır. ${ }^{17}$ Bununla birlikte farklı kullanımlara müsait olan cihad kelimesinin fikıh eserlerinde -yukarıda görüldüğü gibi- çoğunlukla "kılıçla savaş" anlamına gelen "kıtal” manasının tercih edildiği müşahade edilmektedir.

\section{Fürû Fıkıh Kitaplarında Cihad Konusunun Ele Alınışı}

Kur'an ve sünnetin cihad meselesi üzerinde önemle durması, İslâm ilim geleneğinde daha sonra teşekkül eden birçok disiplinin bu konu üzerinde bilhassa durmasını sağlamıştır. Megazî ve siyer türü eserler bunların ilk örneklerindendir. Cihad kelimesinin siyer ve megazî kavramlarıyla yakın ilişki içinde ele alınması, cihad üst başlığı altında işlenebilecek konuların bu iki yazım türü altında inceleniyor olması bu ilişkinin mahiyetini ortaya koymaktadır. Aynı zamanda bu eserler İslâm savaş hukuk kurallarına kaynaklık teşkil etme açısından da başlı başına bir önemi haizdir. ${ }^{18}$

Hicri ikinci asrın ortalarından itibaren cihadla ilgili müstakil eserler yazılmaya başlamakla birlikte cihad konusu, genel olarak fürû fikıh kitaplarının Kitâbü'l-cihad ve Kitâbü's-siyer başlıkları altında ele alınmaktadır. Bu eserlerde işlenen cihad ahkâmı cihadın fazileti, hükmü ve çeşitleri yanında mürtedin durumu, gayrimüslimlerle ilişkiler bağlamında eman, ganimet, müste'men meseleleri ve meşru otoriteye başkaldıranların (bağîler) durumu gibi temel hususlar konu edinmektedir. Bununla birlikte cihad

17 Birçok ayet ve hadis için bk. el-Ankebût 29/69; el-Hac 22/78; en-Nîsâ 4/76; et-Tevbe 9/16, 19, 20, 28, 41; el-Furkân 25/52; el-Mümtehine 60/1; el-Hac 22/78; Ebû 'Abdullah Muhammed b. İsmâ'îl b. İbrâhîm el-Buhârî, el-Câmi 'u'ș-șahîhh, thk. Muhammed Zuheyr b. Nâsır (b.y.: Dâru Tavk en-Necât, 1422), 9 "İman", (No. 26); "Cihâd", 1 (No. 2782); "Cihâd), 2 (2786); Ebû 'Abdirrahmân Ahmed b. Şu'ayb b. 'Alî el-Horâsânî en-Nesâî, es-Sunenul'l-kubrâ, thk. Hasan 'Abdulmun'im eş-Şelebî (Beyrut: Mü' essesetü'r-Risâle, 1421), "Cihâd”, 5 (No. 4296); "Cihâd” 7 (No. 4298); “Cihâd”, 17 (No. 4329); Muhammed b. 'Îsâ b. Sevre b. Mûsa b.ed-Dahhâk et-Tirmizî, Sünen-i Tirmizî, thk. Ahmed. Muhammed Şâkir-Muhammed Fu'âd 'Abdülbâkîì̇brâhîm Utve 'Avd (Misır: Şirketü Mektebeti ve Matbaati Mustafa el-Bâbî el-Halebî, 1395), "Fiten”, 13 (No. 2174); "Fezâilü'l-Cihâd", 1 (No. 1619).

18 Celal Emanet, "Haçlı Seferlerinden Önceki Dönemde İslam'da Cihad Düşüncesi”, EKEV Akademi Dergisi 18/60 (2014), 503-517. 
ahkâmının konu edindiği meseleler modern fikıh literatüründe "savaş hukuku”, “uluslararası ilişkiler” ve “devletler hukuku” kapsamında incelenmektedir. ${ }^{19}$

Hanefî mezhebinin fürû fikıh eserlerine bakıldığında cihad ahkâmı genel olarak Kitâbü's-siyer başlığı altında ele alınmakta, ${ }^{20}$ eserlerin iç tertibinde ise konuya çoğunlukla hâdlerden sonra yer verilmektedir. ${ }^{21} \mathrm{Bu}$ eserlerde cihad kavramı siyer kavramıly irtibatlı bir şekilde incelenmekte, ${ }^{22}$ konunun ele alınış biçimleri yer yer farklılıklar arz etmekle birlikte genel olarak önce söz konusu kitaba niçin o ismin verildiği meselesi üzerinde durulmakta, akabinde ayet ve hadislerden deliller getirilerek konu temellendirilmeye çalışılmaktadır. Daha sonra konu bâb başlıklarına ve zaman zaman fasıllara ayrılarak detaylandırılmaktadır. ${ }^{23}$

Bu mezhepte cihad ahkâmını işleyen en önemli eserlerden biri, Ebû Hanîfe'nin meşhur öğrencisi ve “Devletler Hukuku”nun banisi İmam Muhammed (ö. 189/805) tarafından kaleme alınan el-Asl eserinin birer bölümü olarak kabul edilen ${ }^{24}$ es-Siyerü ’s-

19 Özgür Kavak, "Fıkıh Literatüründe Cihad Hükümleri ve Modern Cihad Yorumları", İç Tehdit ve Riskler Işı̆̆ında İslam Dünyasının Geleceği, ed. Ahmet Emin Dağ (İstanbul: İHH Yayınları, 2016), 225; Ahmet Özel, Dârülislâm-Dârülharb Harb İslâm Hukukunda Ülke Kavramı (İstanbul: İz Yayıncilık, 2019), 26-28.

20 Ebü'l-Hüseyn Ahmed b. Ebî Bekr Muhammed b. Ahmed el-Kudûrî, el-Muhtașar, thk. Kamil Muhammed Uveyze (Beyrut: Daru'l Kütübi’l İlmiyye, 1418), 231-239; Kâsânî, Bedâ'i 'u 's-șanâ'i ', 7/97-141; Ebü'l-Hasen Burhânüddîn 'Alî b. Ebî Bekr b. 'Abdilcelîl el-Mergīnânî - Tallal el-Yusuf, elHidâye fî şerhi Bidâyeti'l-Mübtedî (Beyrut: Dâru'l-İhyâ'i Türâsi'l- 'Arabi, ts.), 2/378-414. Cihad ahkâmının Kitâbü'l-cihad başlığı altında işlendiği birkaç eser için bk. Muhammed Emîn b. Ömer b. Abdilazîz el-Hüseynî ed-Dımaşkî İbn Âbidîn, Reddü'l-muhtâr 'ale'd-Dürri'l-muhtâr (Beyrut: Dâru'lFikr, 1412), 4/119-268; Ebû Muḥammed (Ebü'ṣ-Șenâ) Bedrüddîn el-'Aynî, Minhatü's-sülûk fí şerhi Tuhfetü'l-Mülûk, thk. Ahmed 'Abdurrezzak el-Kebîsî (Katar: Vizâretü'l-Evkāf ve'ş-Şuûni'lİslâmiyye, 1428), 337-365.

21 Ebû Bekr Şemsü'l-e'imme Muhammed b. Ebî Sehl Ahmed es-Serahsî, el-Mebșuṭ (Beyrut: Dâru'lMa rife, 1414), 10/2; Kâsânî, Bedâ'i 'u's-ṣanâ'i', 2/97; Ebü'l-Fazl Mecdüddîn 'Abdullāh b. Mahmûd b. Mevdûd el-Mevsilî, el-İhtiyâr li ta'alili'l-Muhtâr (Beyrut: Matba'atü'l-Halebî, 1356), 9/117. Kudûrî'nin eserinde ise konu Kitâbü'l-ikrâh'tan sonra gelmektedir. Bk. Kudûrî, el-Muhtașar, 231.

22 Kâsânî, siyer kelimesinin sözlük manasının "târik" ve "hey’e" anlamlarına geldiğini, bundan yola çıkarak kitâbüs's-siyer'in, gazilerin (cihad) yollarını, lehlerine ve aleyhlerine olan durumların beyânını içerdiğini, bundan ötürü söz konusu bölüme bu ismin verildiğini belirtmiştir. Kâsânî, Bedâ'i 'u's-șanâ'i', 7/97.

23 Kudûrî, el-Muhtașar, 231-239; Serahsî, el-Mebșuṭ, 10/2; Mevsılî, el-İhtiyâr, 9/124-150.

24 Zâhiru'r-Rivâye eserlerinin sayısı ve es-Siyerü's-săḡir ve es-Siyerü'l-kebîr eserlerinin müstakil birer eser mi yoksa $e l$-Asl'ın birer bölümü olup olmadığıyla ilgili tartışmalar için bk. Okan Kadir Yılmaz, Ilk Tedvin Döneminde Hanefi Mezhebi Literatürünün Kayıp Eserleri (İstanbul: Marmara Üniversitesi, Sosyal Bilimler Enstitüsü, Yüksek Lisans Tezi, 2017), 97-98; Orhan Ençakar, Hanefi Mezhebî Nevâdir literatürü (İstanbul: Marmara Üniversitesi, Sosyal Bilimler Enstitüsü, Doktora Tezi, 2019), 38-43; Murtaza Bedir, Buhara Hukuk Okulu (İstanbul: İSAM Yayınları, 2019), 52. 
sağ̄ir ve es-Siyerü'l-kebîr kitaplarıdır. ${ }^{25}$ Devletler Hukuku alanında kaleme alınan ilk eserin $^{26}$ hangisi olduğu hakkında muhtelif bilgiler olmakla birlikte bu iki çalışma Hanefi mezhebinde bu alanda yazılan ilk eserlerden kabul edilmektedir. ${ }^{27}$

Aşağıda sistematik açıdan, tertip ve metod bakımından Hanefî̀ mezhebinin muteber iki fürû kaynağı olan Bedâ'i'u's-sanâi ve el-İhtiyâr eserlerinde cihad konusunun hangi temel başlıklar altında ele alındığını gösteren bir tablo verilecektir.

25 Ebû Abdillâh Muhammed b. el-Hasen b. Ferkad eş-Şeybânî, es-Siyerü ’s-Sağĝ̂r, thk. Mecîd Haddûrî (Beyrut: ed-Dâru'l-Müttehide, 1975); Ebû Bekr Şemsü'l-e'imme Muhammed b. Ebî Sehl Aḥmed esSerahsî, Şerḥu 's-siyer' 'ūl-kebīr (b.y.: eş-Şeriketu'ş-Şarkiyye lil-İ'lânât, ts.).

26 İlk olarak kimler tarafından, ne zaman, nerede yazıldığı hakkındaki tartışmalar için bk. Ahmet Yaman, "Siyer", Türkiye Diyanet Vakfı İslâm Ansiklopedisi (İstanbul: TDV Yayınlar1, 2009), 37/316319.

27 İki eserde işlenen konuların detayı için bk. Çoban, İslâm Hukukunda Cihad Literatürü ve Bedreddin İbn Cemâa'nın Cihadla İlgili Eserlerinin Değerlendirilmesi, 15-17. 
Tablo 1: Hanefî Fürû Eserlerinde Cihad Konusunun Başlıkları

\begin{tabular}{|c|c|}
\hline $\begin{array}{l}\text { Kasânî (ö. 587/1191), } \\
\text { Bedâ'i 'u's-sanâ'i } \\
\text { Kitâbü's-siyer } \\
\end{array}$ & $\begin{array}{l}\text { Mevs1lî (ö. 683/1284), } \\
\text { el-İhtiyâr } \\
\text { Kitâbü's-siyer }{ }^{29}\end{array}$ \\
\hline Siyer ve Cihad Kelimelerinin Anlamları & Ehl-i Harble Antlaşma Yapmak \\
\hline Cihad Farizasının Keyfiyetinin Beyanı & Emân \\
\hline Cihadın Kimlere Farz Olduğu & Beldelerin Fethi \\
\hline $\begin{array}{l}\text { İmamin Orduyu veya Seriyeyi Cihada } \\
\begin{array}{l}\text { Gönderirken } \\
\text { Gerekenler }\end{array}\end{array}$ & Ganimet \\
\hline $\begin{array}{l}\text { Savaşta Düşmanla Karşılaşıldığında } \\
\text { Mücahidlerin İlk Yapması Gerekenler }\end{array}$ & Ganimet Paylaşımı \\
\hline $\begin{array}{l}\text { Kâfirlerden Katli Helal Olanlar ve } \\
\text { Olmayanlar }\end{array}$ & Ehl-i Harbin Mülkü \\
\hline $\begin{array}{l}\text { Katli Helal Olmayanlardan Dârü'l-Harbde } \\
\text { Birakılabilenler ve Bırakılamayacaklar }\end{array}$ & Cizye \\
\hline $\begin{array}{l}\text { Dârü'l-Harbe Götürülmesi Mekruh Olan } \\
\text { Şeylerle Olmayanlar }\end{array}$ & Haraç \\
\hline $\begin{array}{l}\text { Savaşmaya Mâni Olan Sebepler (İman, } \\
\text { Emân, Hareme Siğınma) }\end{array}$ & Mürted \\
\hline Ganimet ve Onunla İlgili Hükümler & Kâfirin Müslüman Olma Yolları \\
\hline $\begin{array}{l}\text { Kâfirlerin Müslümanların Mallarına } \\
\text { Saldırmasının Hükmü }\end{array}$ & Haricî ve Bağy Ehli \\
\hline Dârü'l-İslâm ve Dârü'l-Harb'in Manası & \\
\hline $\begin{array}{l}\text { Dârü'l- İslâm ve Dârü'l- Harble İlişkili } \\
\text { Hükümler }\end{array}$ & \\
\hline Mürtedin Hükmü & \\
\hline Mürtedin Çocuğunun Hükmü & \\
\hline Bağînin Hükmü & \\
\hline
\end{tabular}

Şâfiî mezhebinin fürû fikıh eserlerine bakıldığında cihad konusu genel olarak, hanefî̀ mezhebinde olduğu gibi Kitâbü s-siyer başlığı altında incelenmekte ${ }^{30}$ ve tasnif

28 Kâsânî, Bedâ'i 'u's-șanâ'i', 7/97-141.

29 Mevsilî, el-íhtiyâr, 9/117-153.

30 Bk. Ebû İsmâ' ̂̂l b. Yahyâ İsmâîl el-Müzenî, Muhtașaru'l Müzenî (Beyrut: Dâru'l-Ma'rife, 1410), 8/376-388; Cemâluddîn İbrâhim b. 'Alî b. Yûsuf Ebû İshâk eş-Şîrâzî, el-Muhezzzeb fí fikhi'l-İmâm eşŞâfi '̂̀ (Beyrut: Dâru'l-Kütübi'l-'İlmiyye, ts.), 3/249-333. Cihad ahkâmının Kitâbü'l-cihâd başlığı altında işlendiği eserler için bk. Ebû 'Abdullah Muhammed b. İdrîs eş-Şâfi î, el-Üm (Beyrut: Dâru'l- 
olarak da konuya hâdlerden sonra yer verilmektedir. ${ }^{31} \mathrm{Bu}$ mezhebin fürû fikıh kaynaklarında hanefî̀ mezhebinde takip edilen, cihad ve cihadla ilgili meselelerin hükmünün bir bütün olarak Kitâbü 's-siyer başlığ edilmekte, muhtelif kitap başlıkları altında bu konulara değinilmektedir. ${ }^{32}$

Aşağıda, Şâfiî mezhebinin en muteber beş eseri arasında sayılan Müzenî’nin elMuhtașar'1 ile Şîrâzî'nin Muhezzzeb'i esas alınarak cihad konusunun bu mezhepte umumiyetle hangi başlıklar altında incelendiğini gösteren bir tablo sunulacaktır.

Tablo 2: Şâfiî Fürû Eserlerinde Cihad Konusunun Başlıkları

\begin{tabular}{|c|c|}
\hline $\begin{array}{l}\text { Müzenî (ö. 264/878) } \\
\text { el-Muhtasar } \\
\text { Kitâbü's-siyer }\end{array}$ & $\begin{array}{l}\text { Şîrâzî (ö. 476/1083) } \\
\text { Muhezzeb } \\
\text { Kitâbü's-siyer }\end{array}$ \\
\hline Fey ve Ganimetin Paylaşımı & Bağy Ehli İle Savaş \\
\hline Bağy Ehli & Mürtedin Katli \\
\hline Mürted & Enfâl \\
\hline $\begin{array}{l}\text { Özrü Sebebiyle Cihada Katılamayacaklar ve } \\
\text { Cihadı Terk Etme Özrü }\end{array}$ & Ganimetin Paylaşımı \\
\hline Cizye ve Risalede Seferberlik (Nefir) & Humûs'un Paylaşımı \\
\hline Müşriklerin Müslümanlardan Aldığı Şeyler & Feyin Paylaşımı \\
\hline $\begin{array}{l}\text { Ganimet Dağıtılmadan Önce Bir Kişinin Bir } \\
\text { Cariyeyle İlişkiye Girmesi, Kişinin } \\
\text { Çocuğunun ve Babasının Ganimetler } \\
\text { Arasında Olması, Esirin Hükmü }\end{array}$ & Cizye \\
\hline
\end{tabular}

Ma'rife, 1410), 4/267-225; Suleymân b. 'Ömer b. Mansûr Cemel, Hâşiyetu'l-Cemel 'alâ Şerḥi'lMenhec= Futûhâtu'l-vehhâb bi-tavdîhi Şerhi Menheci't-țllâb (Beyrut: Dâru'l-Fikr, ts.), 5/179-210.

31 Bk. Şîrâzî, el-Muhezzeb, 3/249; İmâmu'l-Haremeyn el-Cüveynî, Nihâyetu'l-maṭlab fî dirâyet'ilmežheb, thk. 'Abdūl'azîm ed-Dîb (Suudi Arabistan: Dâru'l-Minhâc, 1428), 17/389; Ebû Zekeriyya Muhyiddîn Yahya b. Şerîf en-Nevevî, Minhâcu 't-tâlibîn ve 'umdetu'l-muttakīn fi'l-fikh, thk. Kâsım Ahmed 'Avvad (Beyrut: Dâru'l-Fikr, 2005), 1/307.

32 Örneğin mezhep kurucunun eseri olan el-Ümm'da bu yöntem takip edilmiştir. Eserde cihadla ilgili hükümler fey, cizye, cihad, ridde ve bağy gibi başlıklar altında incelenmiştir. Bk. eş-Şâfi î, el-Üm, 4/145, 167, 226, 919; Ayrica bk. el-Cüveynî, Nihâyetu'l-mațlab, 11/441; 17/5, 389; Nevevî, Minhâcu't-tâlibîn, 1/198, 291, 293, 307.

33 Müzenî, Muhtașaru'l Müzenî, 8/247-254, 363-367, 376-388.

34 Şîrâzî, el-Muhezzzeb, 3/249-333. 


\begin{tabular}{|l|l|}
\hline Mübâreze & Zimmet Akdi \\
\hline $\begin{array}{l}\text { Sevâd Arazilerinin Fethi ve İmamın } \\
\text { Müslümanlara Ait Arazileri Tevkif Etmesi }\end{array}$ & Ateşkes \\
\hline $\begin{array}{l}\text { Fidye ile Serbest Kalamayacağına ya da } \\
\text { Kaçmayacağına Dair Antlaşma Yapılan Esir }\end{array}$ & Sevâd Arazilerin Haracı \\
\hline İslâm'ın Bütün Dinlere Galip Gelmesi & \\
\hline Kimler Ehli Kitaptan Sayılır & \\
\hline $\begin{array}{l}\text { Ehli Kitaba Cizyenin Yüklenmesi Lehlerine } \\
\text { ve Aleyhlerine Sorumlulukların Verilmesi }\end{array}$ & \\
\hline $\begin{array}{l}\text { Hıristiyan Araplardan Vergilerin (sadaka) } \\
\text { Kat Kat Alınması, Cizye Alma Yöntemi }\end{array}$ & \\
\hline $\begin{array}{l}\text { Müslümanların İçinde Bulundukları Durum } \\
\text { Gözetilerek Düşmanla Antlaşma Yapma }\end{array}$ & \\
\hline Zimmîlerin Dinlerini Değiştirmeleri & \\
\hline (Zimmîlik) Antlaşmasının Bozulması & \\
\hline $\begin{array}{l}\text { Antlaşmalıların (Muhadîn) ve Ateşkes } \\
\text { Yapılanların (Muahid) Hükmü }\end{array}$ \\
\hline
\end{tabular}

Mâlikî mezhebinin fürû fikıh literatürüne bakıldığında cihad ahkâmının belirgin bir şekilde Kitâbü'l-cihad başlığı altında incelendiği görülmekte, ${ }^{35}$ tasnif bakımından ise bu konu ibadetlerle birlikte ele alınmaktadır. ${ }^{36}$ Cihad ahkâmını ele almak için mezhebin temel fikıh eserlerinin hemen hemen hiçbirinde siyer kavramı tercih edilmemektedir.

Aşağıda, Mâlikî mezhebinin "ümmehât" diye isimlendirilen eserlerin en önemlilerinden biri olan el-Müdevvenetü'l-kübrâ ve mezhebin beş ana metnini bir araya getiren ez-Zahîre esas alanarak cihad konusunun bu mezhepte hangi temel başlıklar altında incelendiğini gösteren bir tablo verilecektir.

35 Bk. Ebû Saîd Abdüsselâm b. Saîd b. Habîb et-Tenûhî Sahnûn, el-Müdevvenetü'l-kübrâ (Beyrut: Dâru'l-Kütübi'l- İlmiyye, 1415), 1/496-531; Ebü'l-Velîd Muhammed b. Ahmed b. Muhammed elKurtubî İbn Rüşd, Bidâyetü'l-müctehid ve nihâyetü'l-mukteṣıd (Kahire: Dâru'l-Hadîs, 1425), 2/143169; Ebü'l-Abbâs Şihâbüddîn Ahmed b. İdrîs b. Abdirrahmân el-Misrî el-Karâfî, ez-ZZahîre, thk. Se'îd A'râb vd. (Beyrut: Dâru'l-Garbi'l-İslâmî, 1994), 3-4/383-70.

36 Bk. Karâfî, ez-Znahîre, 3/383; Sahnûn, el-Müdevvene, 1/496; Halîl b. İshâk b. Mûsâ el-Cündî, elMuhtașaru'l-Halil, thk. Ahmed Câd (Kâhire: Dâru'l-Hadîs, 1426), 88. 
Tablo 3: Mâlikî Fürû Eserlerinde Cihad Konusunun Başlıkları

\begin{tabular}{|c|c|}
\hline $\begin{array}{l}\text { Sahnûn (ö. 240/854), } \\
\text { el-Müdevvenetü'l-kübrâa } \\
\text { Kitâbü'l-cihâd }{ }^{37}\end{array}$ & $\begin{array}{l}\text { Karâfî (ö. 684/1285), } \\
\text { ez-Zahîre } \\
\text { Kitâbü'l-cihâd } \\
\end{array}$ \\
\hline Savaştan Önce Dine Davet & Cihadın Hükmü \\
\hline Valilerle Savaş & Cihadın Sebepleri \\
\hline Kadınların Savaşa Katılması & Cihadın Şartları \\
\hline Savaşta Çocuk ve Kadınların Öldürülmesi & Cihadın Mânileri \\
\hline Esirlerin Öldürülmesi & Savaş \\
\hline Ganimet Paylaşımı & Kâfirlerin Malları \\
\hline $\begin{array}{l}\text { Kişi Ganimet Paylaşımı Yapılmadan } \\
\text { Kendisine Ait Malını ve Kölesini Tanırsa } \\
\text { Bunların Durumu }\end{array}$ & Beşte Birlik Payın Paylaşımı (Humus) ve Fey \\
\hline $\begin{array}{l}\text { Bir Kişinin Dârü'l-harbe Girip Müslümanlara } \\
\text { Ait bir Köleyi Satın Alması }\end{array}$ & Müşriklerin Ele Geçirdiği Mallar vb. Şeyler \\
\hline $\begin{array}{l}\text { Zimmî Bir Kadınla Bir Müslüman Kadının } \\
\text { Düşmanın Eline Düşmesi ve Orada } \\
\text { Doğurması Daha Sonra Müslümanlar Bunları } \\
\text { Ganimet Olarak Alması }\end{array}$ & et-Te'min \\
\hline $\begin{array}{l}\text { Harbî Birinin Müslümanlara Ait Bir Köleyi } \\
\text { Ele Geçirmiş Olarak Müslüman Olması }\end{array}$ & Ateşkesin Şartları ve Hükümleri \\
\hline $\begin{array}{l}\text { Harbi Birinin Müslüman Olmasından Sonra } \\
\text { Müslümanların Onun Eşini ve Çocuklarını } \\
\text { Ganimet Olarak Alması }\end{array}$ & Cizye \\
\hline $\begin{array}{l}\text { Bir Müslüman Tâcirin Dârü'l-harbe Gidip } \\
\text { Müslüman Bir Köleyi Satın Alıp Azad } \\
\text { Etmesi }\end{array}$ & Müsâbâkâ ve Remy \\
\hline $\begin{array}{l}\text { Zimmînin Ahdini Bozup Dârü'l-harbe } \\
\text { Kaçması ve Daha Sonra Müslümanların } \\
\text { Ganimet Olarak Onu Almaları }\end{array}$ & \\
\hline $\begin{array}{l}\text { Harbî Kölenin Müslüman Olmak İçin Tüccar } \\
\text { Olarak Dârü'l-İslâma Gelmesi ve Yanında } \\
\text { Mevlâsının Mallarının Olması, Bu Malların } \\
\text { Ganimet Olarak Taksim Edilmesi }\end{array}$ & \\
\hline
\end{tabular}

37 Sahnûn, el-Müdevvene, 1/496-531.

38 Karâfî, ez-Zahîre, 3-4/383-70. 


\begin{tabular}{|c|c|}
\hline $\begin{array}{l}\text { Dârü'l-Harbde Müslüman Olan Ehl-î Harb } \\
\text { Kölenin Üzerinde Efendilerinin Mülkiyetinin } \\
\text { Düşüp Düşmemesi }\end{array}$ & \\
\hline $\begin{array}{l}\text { Dârü'l-Harbde Harbî Birinin Kölesinin } \\
\text { Müslüman Olması ve Müslüman Birinin Onu } \\
\text { Satın Alması }\end{array}$ & \\
\hline $\begin{array}{l}\text { Dârü'l-Harbde Harbî Birinin Kölesinin } \\
\text { Müslüman Olması ve Müslümanların Onu } \\
\text { Ganimet Olarak Ele Geçirmeleri }\end{array}$ & \\
\hline $\begin{array}{lll}\text { Arapların } & \text { Esir } & \text { Alındıklarında } \\
\text { Köleleştirilmesi } & & \end{array}$ & \\
\hline $\begin{array}{l}\text { Harbî Müste'men'in Arkasından Mal } \\
\text { Birakarak Ölmesi, Malının Durumu Meselesi }\end{array}$ & \\
\hline $\begin{array}{l}\text { Aralarında Müslüman Esirler Olduğu Halde } \\
\text { Düşmanın Muhasara Altına Alınması }\end{array}$ & \\
\hline Düşmanın Müslüman Gemilerini Yakması & \\
\hline $\begin{array}{l}\text { Fey, Haraç Arazisinin ve Humusun } \\
\text { Paylaşılması }\end{array}$ & \\
\hline $\begin{array}{l}\text { Cizyeden Fey Kısmının Paylaşımı ve İmamın } \\
\text { Ödül Koyması }\end{array}$ & \\
\hline Selb & \\
\hline İmamın Savaşta Ödül Koyması & \\
\hline Savaşta Ganimetten Pay Alma & \\
\hline $\begin{array}{l}\text { Köle, Kadın ve Tüccarın Ganimetten Pay } \\
\text { Alması }\end{array}$ & \\
\hline $\begin{array}{l}\text { Dârü'l-Harbde Kaybolan } \quad \text { Hastanın } \\
\text { Ganimetten Pay Alıp Alamayacağı Meselesi }\end{array}$ & \\
\hline $\begin{array}{l}\text { Ganimet Toplandıktan Sonra Ordunun } \\
\text { Yemek Yemeğe ve Binekleri İçin Yeme } \\
\text { İhtiyaç Duyması }\end{array}$ & \\
\hline $\begin{array}{l}\text { Dârü'l-Harbde Birinin İhtiyacı Kadar } \\
\text { Yiyecek ve Yem Alması ve Arta Kalanını } \\
\text { Bırakarak Memlekete Dönmesi }\end{array}$ & \\
\hline Savaşta İhtiyaç Olmayan ya da Beraberinde & \\
\hline
\end{tabular}




\begin{tabular}{|l|l|}
\hline $\begin{array}{l}\text { Götürülemeyecek Hayvan ve Binekleri } \\
\text { Sakatlama, Silah ve Yiyecekleri Yakma } \\
\text { Hususu }\end{array}$ & \\
\hline $\begin{array}{l}\text { Düşmanla Savaşırken Müşriklerden } \\
\text { Yardımın Talep Edilmesi }\end{array}$ & \\
\hline Çocuk, Kadın ve Kölenin Emân Vermesi & \\
\hline Denizde Murâbıtların Tekbir Getirmesi & \\
\hline Divan & \\
\hline Cualâ & \\
\hline Cizye & \\
\hline Havâric & \\
\hline
\end{tabular}

Hanbelî mezhebi literatürü söz konusu olduğunda ise bazı istisnai durumlar bir kenara birakılacak olursa cihad konusu genel olarak Kitâbü'l-cihâd başlığ1 altında incelenmekte, ${ }^{39}$ tasnif bakımından ise konuya bazen ibadetlerle birlikte bazen de hâdlerden sonra yer verilmektedir. ${ }^{40}$ Şâfiî mezhep kaynaklarında işaret edildiği gibi bu mezhebin eserlerinde de konu yalnızca bir başlık altında ele alınmayıp muhtelif başlıklar altında incelenmektedir. ${ }^{41}$

Aşağıda, Hanbelî mezhebinin önemli iki klasik eseri esas alınarak bu mezhebin fürû kaynaklarında cihadın hangi başlıklar altında ele alındığını gösteren bir tablo verilecektir.

39 Ebü'l-Kâsım Ömer b. Hüseyn b. Abdillâh el-Hırakî, Muhtașaru'l-Hirâkî (Mısır: Dâru's-Sahâbe li’tTurâs, 1413), 138-142; Ebû Muhammed Muvaffakuddîn Abdullâh b. Ahmed b. Muhammed İbn Kudâme, el-Mukni' fì fiḳhi'l-İmâm Ahmed, thk. Mahmud el-Arnavûd - Yasîn Mahmûd el-Hâtib (Cidde: Mektebetü's-Sevâdî li’t-Tevzî‘, 1421), 136-150.

40 İbadetlerle olan yerler için bk. İbn Kudâme, el-Mukni', 136; Muhammed b. Bedreddin b. Bulbân İbn Bedrân, Ahșaru'l-muhtașarât fî'l-fikh 'alâ mezhhebi'l-imâm Aḥmed b. Hanbel, thk. Muhammed Nâsır el-'Acmî (Beyrut: Daru'l-Beşa' iri'l-İslamiyye, 1416), 161. Hadlerden sonra için bk. Hirakî, Muhtașaru'l-Hirâkî, 138; Ebû Muhammed Muvaffakuddîn Abdullâh b. Ahmed b. Muhammed İbn Kudâme, el-Muginn̂̀ (Kâhire: Mektebetü'l-Kâhire, 1388), 9/196-327.

41 Hirakî, Muhtașaru'l-Hirâkî̀, 95, 132, 142; İbn Kudâme, el-Muginn̂, 6/453; 8/523; 9/3-328. 
Tablo 4: Hanbelî Fürû Eserlerinde Cihad Konusunun Başlıkları

\begin{tabular}{|l|l|}
\hline $\begin{array}{l}\text { Hirakî (ö. 334/946), } \\
\text { el-Muhtasar } \\
\text { Kitâbü'l-cihâd }{ }^{42}\end{array}$ & $\begin{array}{l}\text { İbn Kudâme (ö. 620/1223), } \\
\text { el-Muknî } \\
\text { Kitâbü'l-cihâd }{ }^{43}\end{array}$ \\
\hline Sadaka, Ganimet ve Fey'in Paylaşımı & İmam ve Ordunun Sorumlulukları \\
\hline Mürted & Ganimetin Paylaşımı \\
\hline Cihad & Ganimet Arazilerin Hükmü \\
\hline Cizye & Fey \\
\hline & Emân \\
\hline & Hüdne (ateşkes- antlaşma) \\
\hline & Zimmet Akdi \\
\hline & Zimmet Akdinin Hükmü \\
\hline
\end{tabular}

Dört sünnî mezhep dışında Zâhirî mezhebine bakıldığında cihad ahkâmının Kitâbü'l-cihad başlığı altında ele alındığı ve tasnif bakımından da konuya ibadetlerden sonra yer verildiği görülmektedir. ${ }^{44}$

\section{3 İslâmî Literatürde Cihadla İlgili Eserler}

Tedvin faaliyetlerinin başladığı hicri II. asrın ortalarından itibaren cihad konusunu ele alan çalışmalar ortaya çıkmış ve bu konuda günümüze kadar zengin bir literatür meydana gelmiştir. Cihad konusu tedvin faaliyetlerinin başlarında ağırlıklı olarak hadis ve fikıh eserlerinin kitâbü'l-cihad, kitâbü's-siyer ve fâzlü'l-cihad başlıkları altında incelenmiş ve zamanla siyâset-i şeriyye, edeb, kelam-mezhepler tarihi gibi muhtelif disiplinlerin odak noktalarından biri haline gelmiştir. Aynı zamanda bu eserlere paralel olarak konuyla ilgili birçok müstakil risale ve çalışma da kaleme alınmıştır. Bu durum da söz konusu edebiyatın tarihi süreçteki keyfiyet ve kemiyetinin ortaya

42 Hirakî, Muhtașaru'l-Hirâḳ̂, 138-142.

43 İbn Kudâme, el-Mukni', 136-150.

44 Ebû Muhammed 'Alî b. Ahmed b. Saîd İbn Hazm, el-Muhallâ bi'l-âsâr fì şerhì 'l-Mücellâ bi'l-ihtișâr (Beyrut: Dâru'l-Fikr, ts.), 5/340;11/333; 12/272. 
çıkarılmasını gerektirmiş, konuyla ilgili yazılmış literatürün bir araya getirilmesinin gerekliliğini gözler önüne sermiştir.

Makalenin bu bölümünde yaptığımız araştırma neticesinde cihad konusu hakkında hicri ilk asırlardan yirminci yüzyılın ortalarına kadar kaleme alınan risale ve kitapların listesi bir tasnif dâhilinde aşağıda sunulacaktır. ${ }^{45}$ Burada öncelikle klasik ve modern şeklinde ikili bir ayırıma gidilerek okuyucunun tarihi serencamı takip etmesinin kolaylaştırılması hedeflenmiştir. Dönemlendirmelerde birçok kıstas olmakla birlikte biz burada İslâm dünyası için önemli dinî, siyâsî ve sosyal etkiyi haiz olmasından ötürü modern dönem tarihlendirmesi için Fransa'nın Mısır'ı işgal ettiği 1798 yılını başlangıç tarihi olarak esas aldık. ${ }^{46}$ Bununla birlikte eserler ölüm tarihi tespit edilen müellifler esas alınarak kronolojik bir sıra halinde listelenmiş, ölüm tarihi tespit edilemeyen müellifler ise alfabetik olarak sıralanmıştır. Bahsi geçen eserler hakkında da yer yer kısa bilgiler verilmeye çalışılmıştır.

Ulaşılan eserlerin tespitinde biyobibliyografik eserlerden, müstakil olarak cihad konusunu ele alan çalışmalardan, bu çalışmaların kullandığı kaynaklardan ve kaynakçalarından, muhtelif kataloglardan ve genel taramalardan istifade edilmiştir. Yazma eser nüshalarını tespit hususunda ise Türkiye Yazma Eserler Kurumu, İSAM ve muhtelif kütüphane veritabanlarına müracaat edilmiştir.

$\mathrm{Bu}$ çalışma, cihad alanında ilk dönemlerden günümüze kadar yazılan bütün eserleri tespit etme iddiasında olmayıp araştırma neticesinde ulaşılabilen eserleri içermektedir. $^{47}$

45 Cihad konusunda kaleme alınan makale ve modern çalışmaların bir listesi için bk. Çoban, İslâm Hukukunda Cihad Literatürü ve Bedreddin İbn Cemâa'nın Cihadla Ilgili Eserlerinin Değerlendirilmesi, 51-65, 67-99. Osmanlı cihad risalelerini ve Osmanlının son döneminde cihad konusunda yazılan makaleleri konu edinen müstakil bir çalışma için bk. Abdullah Taha İmamoğlu, "I. Dünya Savaşı'na Bibliyografik Bir Katkı: Osmanlı'da Cihad Risâleleri”, 100. Yllında Birinci Dünya Savaşı ve Mirası, ed. Halil Çetin - Lokman Erdemir (Savaş Tarihi Araştırmaları Uluslararası Kongresi, Çanakkale, 2015), 151-179. Konu hakkında yapılan bir başka çalışma için bk. Ömer Faruk Akpınar, "İslam Edebiyatında Kitâbü'l-Cihâdların Muhteva Gelişimi”, Savaş ve Edebiyat, ed. Yılmaz Daşcıoğlu (Sakarya: Sakarya Üniversitesi Basımevi, 2016), 255-283.

46 Bk. Davut Dursun, "Günümüz İslâm Dünyası", Türkiye Diyanet Vakfi İslâm Ansiklopedisi (İstanbul: TDV Yayınları, 2001), 23/32-36.

47 Bu çalışma, cihad alanında yazılan makaleleri ve yirminci yüzyılın ortalarından günümüze kadar neşredilen modern çalışmaları ihtiva etmemektedir. Çalışmadaki değerlendirmeler araştırma neticesinde -makalenin başlığında belirtilen zaman aralığında- ulaşılan kitap ve risaleler üzerinde 


\subsection{Klasik Dönemde Yazılan Eserler}

\subsubsection{Kitaplar}

1. Abdullâh b. Mübârek, Ebû Abdirrahmân b. Vâzıh el-Hanzalî el-Mervezî (ö. 181/797), Kitâbü'l-cihâd. ${ }^{48}$ Cihad konusunda yazılan ilk eser hüviyetindedir. Cihadın önemi, fazileti ve dindeki konumu hakkındaki 262 rivayeti derlemiştir. ${ }^{49}$ 2. el-Velîd b. Müslim (195/810), el-Cihâd. ${ }^{50}$

3. Davud ez-Zâhirî, Ebû Süleymân Alî b. Halef el-İsfahânî (ö. 270/884), Kitâbü'l-cihâd. ${ }^{51}$

4. İbn Ebi'd-Dünyâ, Ebû Bekr Abdullâh b. Muhammed b. Ubeyd el-Kureşî elBağdâdî (ö. 281/894), Kitâbü'l-cihâd. ${ }^{52}$

5. İbn Ebî Asım, Ebû Bekr Ahmed b. Amr b. ed-Dahhâk b. Mahled eş-Şeybânî (ö. 287/900), Kitâbü'l-cihâd. ${ }^{53}$

6. Kummî, Ebû Ca'fer Muhammed b. el-Hasen b. Ferrûh es-Saffâr (ö. 290/903), Kitâbü'l-cihâd. ${ }^{54}$

yapılmıştır.

48 Hacı Halife Mustafa b. Abdullah Kâtip Çelebî, Keşfü'z-ẓunûn 'an esâmi 'l-kütüb ve'l-fünûn (Ankara: MEB Yayınları, 1941), 2/1275,1410; Bağdatlı İsmail Paşa, Hediyyetü'l- 'ârifin esmâ 'ü'l-mü' ellifín ve âsârü'l-muṣannifin, thk. Avni Aktuç vd. (İstanbul: MEB Yayınları, 1955), 1/438. Nezih Hammâd tarafından 1982 yllında Tunus'ta (Dârü't-Tunusiyye) ve 2009'da Cidde: Dârü'l-Matbûâtü'l-Hadîs'ta neşredilmiştir. Eser İshak Doğan (Konya: Menba Yayınları, 2008) ve Muhammed Adil Teymur (İstanbul: Otağ Yayınevi, 1980) tarafından Türkçe'ye çevrilmiştir.

49 Raşit Küçük, "Abdullah b. Mübârek", Türkiye Diyanet Vakfi İslâm Ansiklopedisi (İstanbul: TDV Yayınları, 1988), 1/1/122-124.

50 Ebü'l-Fazl Şihâbüddîn Ahmed b. Alî b. Muhammed İbn Hacer el-Askalânî, Fetḥu'l-bârî bi-şerḥi Șahîhi'l-Buhârî̀ (Beyrut: Daru'l-Ma'rife, 1379), 5/66.

51 Ebü’l-Ferec Muhammed b. Ebî Ya'kûb İshâk b. Muhammed b. İshâk en-Nedîm, el-Fihrist, thk. İbrahim Ramazan (Beyrut: Daru'l-Ma' rife, 1417), 268.

52 Ebû Abdillâh Şemsüddîn Muhammed b. Ahmed b. Osmân ez-Zehebî, Siyeru a 'lâmi'n-nübelâ', thk. Şu 'ayb el-Arnavût (b.y.: Müessesetü'r-Risâle, 1405), 13/402.

53 Eser Ebû Abdurrahman el-Hâmid tarafindan 1409/1989 y1lında Medine'de neşredilmiştir. Bk. Raşit Küçük, "İbn Ebû Âsım”, Türkiye Diyanet Vakfı İslâm Ansiklopedisi (İstanbul: TDV Yayınları, 1999), 19/422-423.

54 Bağdatlı İsmail Paşa, İ̇âhhu'l-meknûn fi'zz-zeyli 'alâ Keşfi'z-zunûn an esâmi'l-kütüb ve'l-fünûn, thk. Şerefettin Yaltkaya, Kilisli Rifat Bilge (Beyrut: Dâru İhyâi't-Türâsi'l- 'Arabî, ts.), 2/287; Bağdatlı İsmail Paşa, Hediyyetü'l-'ârifin, 2/24; Ömer Rızâ Kehhâle, Mu 'cemü'l-mü'ellifîn: Terâcimü mușannifi'l-kütübi'l- 'Arabiyye (Beyrut: Mektebetü Mesnâ, ts.), 9/208. 
7. İbn Hüzeyme, Ebû Bekr Muhammed b. İshâk b. Huzeyme es-Sülemî enNîsâbûrî (311/924), Kitâbü'l-cihâd. ${ }^{55}$

8. Ebû İshâk İbrahim b. Hammâd b. İshâk b. İsmâil el-Bağdâdî el-Mâlikî (ö. 320/932), Kitâbü'l-cihâd. ${ }^{56}$

9. el Kurtûbî, Sabit b. Nezir el-Mâlikî (ö. 318/930), Kitâbü'l-cihâd. ${ }^{57}$

10. İbrahim el-Ezdî, Ebû İshâk Neccâr el-Basrî el-Mâlikî (ö. 323/935), Kitâbü'lcihâd. ${ }^{58}$

11. el-İskâfî, Ebû Alî Muhammed b. Ahmed b. el-Cüneyd (ö. 381/991), İzhâru mâ seterehû ehlü'l- 'inâd mine'r-rivâyeti 'an eimmeti li'l-âşreti fî emri'l-cihâd, ${ }^{59}$ Kitâbü'l-cihâd, ${ }^{60}$ el-İstinfâr ile 'l-cihâd. ${ }^{61}$

12. İbn Batta, Ebû Abdillâh Ubeydullah b. Muhammed b. Muhammed elUkberî (ö. 387/997), Kitâbü'l-cihâd ya da Seb 'ûne hadîsen fi'l-cihâd. ${ }^{62}$

13. el- Hattâbî, Ebû Süleymân Hamd (Ahmed) b. Muhammed b. İbrâhîm b. Hattâb el-Büstî (ö. 388/998), Kitâbü'l-cihâd. ${ }^{63}$

14. el-Bâkıllânî, Ebû Bekr Muhammed b. Tayyib b. Muhammed el-Basrî (ö. 403/1013), Fâzlü'l-cihâd. Eserin günümüze ulaşıp ulaşmadığı bilinmemektedir. ${ }^{64}$ 15. es-Sülemî, Ebû'l-Hasan Ali b. Tahir b. Cafer Kâsım ed-Dımaşkî en-Nahvî (ö. 500/1106), Kitâbü'l-cihâd el-müştemel âlâ'l-hâs âleyhî ve't-terğîb fîhî. ${ }^{65}$

55 Mustafa Işı, “İbn Huzeyme”, Türkiye Diyanet Vakfi İslâm Ansiklopedisi (İstanbul: TDV Yayınları, 1999), 20/80.

56 Bağdatlı İsmail Paşa, Hediyyetü'l- 'ârifîn, 1/5.

57 Kâtip Çelebî, Keşfü’z-zunûn, 2/1410; Bağdatlı İsmail Paşa, Hediyyetü'l- 'ârifìn, 1/248; Kehhâle, Mu'cemü'l-mü'ellifin, 3/100, 103

58 Kehhâle, $M u$ 'cemü'l-mü'ellifin, 1/26.

59 Bağdatlı İsmail Paşa, İ̇âhu'l-meknûn, 1/96.

60 Bağdatlı İsmail Paşa, İ̇̇âhu'l-meknûn, 2/287; Bağdatlı İsmail Paşa, Hediyyetü'l-'ârifîn, $2 / 52$ Hediyyetü'l-ârifîn'de ölüm yılı 281 olarak geçmektedir.

61 Kehhâle, $M u$ 'cemü'l-mü'ellifin, 8/248.

62 Yüsrî Abdülganî el-Bişrî tarafından 1409/1989 yılında Kahire’de neşredilmiştir. Bk. Saffet Köse, "İbn Batta”, Türkiye Diyanet Vakfi İslâm Ansiklopedisi (İstanbul: TDV Yayınları, 1999), 19/358-359.

63 Kâtip Çelebî, Keşfü'z-ẓunûn, 2/1410; Bağdatlı İsmail Paşa, Hediyyetü'l- 'ârifîn, 1/168.

64 Şerafettin Gölcük, "Bâkıllânî”, Türkiye Diyanet Vakfi İslâm Ansiklopedisi (İstanbul: TDV Yayınları, 1991), 4/535.

65 Bağdatlı İsmail Paşa, İżâhu'l-meknûn, 2/287; Hizânetü’t-turâs’ta “el-Cihad” şeklinde geçmektedir. Bk. Merkezü'l-Melik Faysal, Hizânetü't-turâs, 69/405. Müstakil bir çalışma için bk. Âsım Mustafa Âkâle, Yusuf Ahmed Beni Yasin, "Kitâbü'l-Cihâd li’s-Sülemî: Dîrâsâtün fî̀ Mesâdirihi ve Menhecihi ve Rü'yetihi li's-Sirâi'l-İslâmî-el-Frencî'l-Sâlîbî', el- 'Ulumu'l-İnsâniye ve 'l-İctima ìye 41/3 (2014), 929-945. 
16. İbn Tûmert, Ebû Abdillâh Muhammed b. Abdillâh el-Berberî es-Sûsî (ö. 524/1130), Kitâbü'l-cihâd.

17. el-Melikü'l-Efdâl, Necmüddin Eyyûb b. Şazi b. Mervân (ö. 568/1172), Kitâbü'l-cihâd fì sebîlî münşiîl ibâd. ${ }^{66}$

18. İbn Asâkir, Ebü'l-Kâsım Alî b. el-Hasen b. Hibetillâh b. Abdillâh b. Hüseyn ed-Dımaşkî eş-Şâfîi (ö. 571/1176), el-Erbaûn fi'l-ictihad fi ikâmeti'l-cihâd, elİctihâd fi ikâmeti fârzi'l-cihâd, el-Erbaûn fì (hassi âle) 'l-cihâd. ${ }^{67}$

19. Kâdîhan, Ebü'l-Mehâsin Fahrüddîn Hasen b. Mansûr b. Mahmûd el-Özcendî el-Fergânî (ö. 592/1196), Terhibü'l-ibâd ile'l-gâzvî ve'l-cihâd. ${ }^{68}$

20. İbn Cehbel, Mecdûddin Tahir b. Nasrullâh el-Hâlebî eş-Şâfiî (ö. 596/1200), Fezâilü'l-cihâd. Müellif bu eseri Nurettin Zengî için kaleme almıştır. ${ }^{69}$

21. İbn Asâkir, Ebû Muhammed Bahâüddîn el-Kâsım b. Alî b. el-Hasen edDımaşkî (ö. 600/1203), Fezâilü'l-cihâd, ${ }^{70}$ el-Müntekâ min kitâbi fâzli’l-cihâd ve mâ e 'addallâhü li’l- 'ibâd..$^{71}$

22. el-Cemmâîlî, Ebû Muhammed Takıyyüddîn Abdülganî b. Abdilvâhid b. Alî el-Makdisî (ö. 600/1203), Tuhfetü 't-tâlibîn fi'l-cihâd ve'l-mücâhidîn, ${ }^{72}$ Fâzlü'lcihâd $d^{73}$

66 $\quad$ Necmüddin Eyyûb b. Şazi b. Mervân Melikü’l-Efdâl, Kitâbü 'l-cihâd fí sebîlî münşi ìl ibâd. (İstanbul: Süleymaniye Kütüphanesi, Ayasofya, 2002), 1a-20b.

67 Kâtip Çelebî, Keş̧ü'z-zunûn, 1/535; Bağdatlı İsmail Paşa, Hediyyetü'l- 'ârifinn, 1/701. Eser Abdullah İbn Yusuf tarafindan Kuveyt: Dârü'l-Hulefâ'da 1984 yılında tahkik edilerek neşredilmiştir.

68 Ebü'l-Mehâsin Fahrüddîn Hasen b. Mansûr b. Mahmûd el-Özcendî el-Fergânî Kâdîhan, Terhibü’libâd ile'l-gâzvî ve'l-cihâd (Süleymaniye Kütüphanesi, Fatih, 3481), 1a-45b.

69 Kâtip Çelebî, Kessfü'z-zunûn, 2/1275; Bağdatlı İsmail Paşa, Hediyyetü'l-'ârifín, 1/430; Kehhâle, Mu 'cemü'l-mü' ellifin, 5/39. Keşfü'z-zünûn' da müellifin ölüm tarihi 571 olarak verilmiștir.

70 Bağdatlı İsmail Paşa, Hediyyetü'l- 'ârifinn, 1/828; Kehhâle, Mu'cemü'l-mü'ellifin, 8/106. Ebû'l-Kâsım İbn Asâkir'in oğlu olup tarihçi ve muhaddis yönüyle öne çıkmaktadır. Bu eser Kitâbü'l-cihâd şeklinde de isimlendirilmiştir. Eser, Haçlılara karşı müslümanları savaşa teşvik etmek için kaleme alınmış, Selahaddin Eyyûbî̀ye takdim edilmiştir. Bk. S. Kemal Sandıkçı, "Ebû Muhammed İbn Asâkir”, Türkiye Diyanet Vakfi İslâm Ansiklopedisi (İstanbul: TDV Yayınları, 1999), 19/320-321.

71 İbn Asâkîr'in (Ebû Muhammed) Fezâilü'l-cihâd eserinin muhtasar edilmiş halidir. İsam veri tabanında bu eser müellifin babasına isnat edilmiştir.

72 Bağdatlı İsmail Paşa, Hediyyetü'l- 'ârifín, 1/589.

73 Muhammed Nâsıruddîn Elbânî, Fihrisü mahtûtâti dâri'l-kütübi'z-zâhiriyye (Riyad: Mektebetü Maârif, 2001), 477. 
23. et-Tecîbî, Ebû Abdullâh Muhammed b. Abdurrahman b. Ali el-Muhâdis elİşbîlî (ö. 610/1213), Terğı̂̉bü'l-cihâd. ${ }^{74}$

24. el-Herevî, Ebü'l-Hasen Takıyyüddîn Alî b. Ebî Bekr b. Alî el-Mevsılî (ö. 611/1215), et-Tezkiretü'l-Hereviyye fi'l-hiyeli'l-harbiyye. Harp sanatını konu edinen eser el-Melikü’z-Zâhir Gâzî için kaleme alınmıştır. ${ }^{75}$

25. ed-Dâkîkî, Süleyman b. Benin b. Hâlef el-Misrî el-Hanefî̀ (ö. 614/1217), Istibâü'l-cihâd ve edevâtü'l-sâfinâtü'l-ciyâd. ${ }^{76}$

26. Mukrî, Ebü'l-Ferec Afifüddin Muhammed b. Abdurrahmân (ö. 618/1221), Kitâbü'l-erbaîn fi'l-cihâd ve'l-mücâhidîn. ${ }^{77}$

27. İbnü'l-Munâsif, Ebû Abdullâh Muhammed b. İsa b. Muhammed b. Esbağ (ö. 620/1224), el-íncâd fi ebvâbi'l-cihâd. ${ }^{78}$

28. ed-Dımaşkî, Şemsuddîn Ebu'l-Abbâs Ahmed b. Abdulvâhid el-Makdisî elBuhârî (623/1223), Fâzlü'l-cihâd ve'l-mücâhidîn. ${ }^{79}$

29. İbnü'l-Esîr, Ebü'l-Hasen İzzüddîn Alî b. Muhammed el-Cezerî (ö. 630/1233), Kitâbü'l-cihâd. ${ }^{80}$

30. İbn Şeddâd, Yusuf b. Râfi' b. Temim el-Mûsilî (ö. 632/1234), Fezâilü'lcihâd. Eser, Selahaddin Eyyûbî için kaleme alınmıştır. ${ }^{81}$

31. İbnü'l-Hanbelî, Ebü'l-Ferec Nâsıhuddîn Abdurrahmân b. Necm b. Abdilvehhâb el-Ensârî eş-Şirâzî ed-Dımaşkî (ö. 634/1236), Kitâbü'l-incâd fî’lcihâd. ${ }^{82}$

74 Bağdatlı İsmail Paşa, İ̇âhu'l-meknûn, 1/282; Bağdatlı İsmail Paşa, Hediyyetü'l- ârifín, 2/109. Hediyyetü 'l-ârifîn'de eserin ismi Kitâbü 't-terhîb fi'l-cihâd şeklinde geçmektedir.

75 Bağdatlı İsmail Paşa, Hediyyetü'l- 'ârifin, 1/705.

76 Bağdatlı İsmail Paşa, İzâhü'l-meknûn, 2/69; a.mlf., Hediyyetü 'l-ârifin, 1/398.

77 Eser Bedr b. Abdullah Bedr tarafından Beyrut’ta Dârü İbn Hazm yayınlarından 1992 yılında tahkiki edilerek neşredilmiştir.

78 Eser 2003 yılında Aziz el-Vezzânî tarafından Beyrut’ta Dârü'l-Garbi'l-İ̇slâmî yayınlarından tahkik edilerek neşredilmiştir.

79 Elbânî, Fihrisü'z-zâhiriyye, 309-310.

80 Kâtip Çelebî, Keş̧ü'z-zunûn, 2/1410; Bağdatlı İsmail Paşa, Hediyyetü'l- ârifinn, 1/706; Kehhâle, Ми'сетӥ'l-mü'ellifin, $7 / 229$.

81 Kâtip Çelebî, Keşfü'z-zunûn, 2/1275; Bağdatlı İsmail Paşa, Hediyyetü'l- ârifîn, 2/554.

82 Bağdatlı İsmail Paşa, Hediyyetü'l- 'arifin, 1/524; Kehhâle, Mu 'cemü 'l-mü' ellifin, 5/197. 
32. İbnü't-Taylâsân, Kâsım b. Muhammed b. Ahmed (ö. 643/1245), Büğyetü'lvekkâd fì't-târifi büsmetü'l-cihâd. ${ }^{83}$

33. Ziyâeddin el-Makdisî, Ebû Abdillâh Muhammed b. Abdilvâhid b. Ahmed elMakdisî es-Sa“dî Kâsım ed-Dımaşkî (ö. 643/1245), Fezâîlü'l-cihâd. ${ }^{84}$

34. İbn Karatekin, Ebû'l-'Âvâle Sâduddîn Mürtefi' b. Cüzeyl (ö. 647'den sonra), Süblü'r-reşad fì fâzli'l-cihâd. Müellif bu eseri 647 y1lında Melik Necmeddin Eyyûbî için kaleme almıştır. ${ }^{85}$

35. İbn Abdüsselâm, Ebû Muhammed İzzüddîn Abdülazîz b. Abdisselâm b. Ebi'l-Kâsım es-Sülemî ed-Dımaşkî (ö. 660/1262), Ahkâmü'l-cihâd ve fezâilühû.

36. Merrâkûşî, Ebû Abdullâh Muhammed b. Musa b. Numan et-Tilimsânî (ö. 683/1284), E'lâmü'l-ecnâd ve'l 'ibâd ehli'l-ictihâd fâzlü'r-ribât ve'l-cihâd. ${ }^{86}$

37. et-Trablûsî, Abdülhamid b. Ebû'l-Berakât b. İmrân es-Sedefî (ö. 684/1285), Müzekki'l-fuâd fi'l-hâzzi âla'l-cihâd. ${ }^{87}$

38. Kutbü'l-Misrî, Kutbettin Ebubekir Muhammed b. Ahmed eş-Şâfiî (ö. 686/1287), Vesîletü'l- 'ibâd fî fâzîleti’l-cihâd. ${ }^{88}$

39. ed-Dimyâtî, Şerefuddîn Ebû Muhammed Abdülmü'min b. Halef eş-Şâfiî (705/1306), el-Erbaûn fi'l-cihâd. ${ }^{89}$

40. en-Nusaybî, Muhammed b. Muhammed b. Îsâ b. Ma'tûk eş-Şeybânî (707/1307), Fezâilü'l-cihâd. ${ }^{90}$

41. İbnü'z-Zübeyr es-Sekafî, Ebû Ca'fer Ahmed b. İbrâhîm b. ez-Zübeyr elGirnâtî el-Endelüsî (ö. 708/1308), Sebîlü'r-reşâd fí fâzli'l-cihâd. ${ }^{91}$

83 Kâtip Çelebî, Keşfü'z̧-z̧unûn, 1/251; Bağdatlı İsmail Paşa, Hediyyetü'l- 'ârifinn, 1/829; Kehhâle, Mu 'cemü'l-mü'ellifin, 8/113.

84 Bağdatlı İsmail Paşa, Hediyyetü'l- 'ârifin, 2/123.

85 Kâtip Çelebî, Keşfü'z-z̧unûn, 2/978; Bağdatlı İsmail Paşa, Hediyyetü'l- 'ârifîn, 2/425; Kehhâle, Mu'cemü'l-mü'ellifin, 7/217.

86 Bağdatlı İsmail Paşa, Hediyyetü'l- 'ârifin, 2/134; Kehhâle, Mu 'cemü'l-mü'ellifin, 12/68.

87 Kehhâle, $M u$ 'cemü'l-mü'ellifin, 5/99.

88 Bağdatlı İsmail Paşa, İ̇âhhu'l-meknûn, 2/707; Bağdatlı İsmail Paşa, Hediyyetü'l- 'ârifín, 2/135.

89 Ebû Ya'lâ el-Mağribî el-Beydâvî, et-Ta'lîkâtü'l-müstazrafe ala Risâleti’l-Mustatrafe (b.y.: y.y., ts.), 7/70.

90 Kehhâle, Mu 'cemü'l-mü'ellifin, 11/256-257.

91 Bağdatlı İsmail Paşa, İ̇âhu'l-meknûn, 2/5. 
42. el-Attâr, Alâuddîn Ebû'l-Hasen Ali b. İbrahim b. Dâvûd eş-Şâfiî (ö. 724/1324), Fâzlü'l-cihâd. ${ }^{92}$

43. el-Aksarâyî, İsâ b. Yahyâ (ö. 727/1327), Fâzlü'l-cihâd ve ta 'limü'lfurûsiyye. ${ }^{93}$

44. İbn Cemaâ, Ebû Abdillâh Bedrüddîn Muhammed b. İbrâhîm b. Sa'dillâh elKinânî el-Hâmevî (ö. 733/1333), Tahrîrü'l-ahkâm fî̀ tedbîrî ehli'l-İslâm, ${ }^{94}$ Tecnîdü'l-ecnâd ve cihâtü'l-cihâd, ${ }^{95}$ Müstenedü'l-ecnâd fî âlâti'l-cihâd. ${ }^{96}$

45. Tayboğa el-Eşrefî (ö. 770/1368), Kitâb fi'l-cihâd ve'l-furûsiyye ve funûnü'ladâbi'l-harbiyye.

46. İbn Kesir, Ebü'l-Fidâ' İmâdüddîn İsmâîl b. Şihâbiddîn Ömer b. Kesîr b. Dav’ b. Kesîr el-Kaysî el-Kureşî el-Busrâvî ed-Dımaşkî eş-Şâfiî (ö. 774/1373), elİctihâd fi tâlebi'l-cihâd. Müellif bu eseri Frac, iyas kalesini kuşattığında Emir Mencük için kaleme almıştır. ${ }^{97}$ Eser, Haçlılar'a karşı müslümanları cihada teşvik amaciyla Seyfeddin Mencek'in talebi doğrultusunda İbn Teymiyye'nin esSiyâsetü'ş-şer 'iyye eserinden istifadeyle kaleme alınmıştır. ${ }^{98}$

47. el-Verrâk, Tâcuddîn Mahmûd b. Muhammed Sâfiyuddîn (ö. 798/1396 y1lından sonra), Tuhfetü'l-sâlâtîn fì'l-cihâd. ${ }^{99}$

Kehhâle, $M u$ 'cemü'l-mü' ellifin, 7/5.
Kehhâle, $M u$ 'cemü'l-mü' ellifin, $8 / 35$.

94 Kâtip Çelebî, Keşfü'ż-zunûn, 1/356. El-Melikü'l-Eşref için telif edilen eser, Fuâd Abdülmün'im Ahmed tarafından 1408/1988'de Katar'da Dârü’s-sekâfe'de neşredilmiştir. Özgür Kavak tarafından Adle Boyun Ĕgmek (Ehl-i İslâmın Yönetimi İçin Hükümler) ismiyle Türkçeye tercüme edilmiştir (İstanbul: Klasik Yayınları, 2010). İbn Cemâa'nın bu üç eseri hakkında detaylı bilgi için bk. Mehmet Çoban, İslâm Hukukunda Cihad Literatürü ve Bedreddin İbn Cemâa'nın Cihadla İlgili Eserlerinin Değerlendirilmesi (İstanbul: Marmara Üniversitesi, Sosyal Bilimler Enstitüsü, Yüksek Lisans Tezi, 2020), 131-173.

95 Bağdatlı İsmail Paşa, İ̇âhư'l-meknûn , 1/229; Bağdatlı İsmail Paşa, Hediyyetü'l- 'ârifîn , 2/148. Üsâme Nâsır en-Nakşibendî tarafından 1983'te Bağdat'ta Muhtasar fî fâzli'l-cihâd ismiyle neşredilmiştir (Dâirâtü'ş-şuûni's-sekâfiyye li'n-neşr).

96 Bağdatlı İsmail Paşa, İżâhu'l-meknûn, 2/478

97 Kâtip Çelebî, Keşfü'ż-z̧unûn, 1/1; Bağdatlı İsmail Paşa, Hediyyetü'l- 'ârifîn, 1/215.

98 Abdülkerim Özaydın Özaydın, "İbn Kesîr", Türkiye Diyanet Vakfi İslâm Ansiklopedisi (İstanbul: TDV Yayınları, 1999), 20/132-134. Eser, 1347/1928'de ilk defa yayınlamış olup Abdullah Abdürrahîm Useylân (Riyad 1401/1981, 1402/1982, 1412/1992) ve Muhammed Zeynühüm (Kahire 1413/1993) tarafindan neşredilmiştir.

99 Bağdatlı İsmail Paşa, Îzâhụ'l-meknûn, 1/250; Bağdatlı İsmail Paşa, Hediyyetü'l- 'ârifîn, 2/409; Kehhâle, Mu 'cemü'l-mü' ellifin, 12/196. 
48. İbn Hüzeyl, Ebü’l-Hasen Alî b. Abdirrahmân el-Fezârî el-Endelüsî (ö. VIII/XIV), Tuhfetü'l-enfüs ve şi 'ârü sükkâni'l-Endelüs. ${ }^{100}$

49. el-Ba'li, Şemsuddîn Ebû Abdullah muhammed b. Osman b. Abdullah (ö. 803/1401), Kitâb fi'l-cihâd. ${ }^{101}$

50. İbnû'n-Nehhâs ed-Dımaşkî, Ebû Zekeriyyâ Muhyiddîn Ahmed b. İbrâhîm b. Muhammed (ö. 814/1411), Meşâri 'ü'l-eşvâk ilâ meşâri 'i’l- 'uşşâk ve müssîrü'lgarâm ilâ dâri's-selâm, fezâilü'l-cihâd türü bir eserdir. Eser, birçok kitaptan faydalanılarak kaleme alınmış (örneğin İbn Âsâkîr'in eseri gibi), Şair Bâki Efendi tarafından vezir Mehmet Paşa için Türkçeye tercüme edilmiştir. ${ }^{102}$ Müellifin kendisi tarafindan Fükâhetü'l-ezvâk min Meşâri'i’l-eşvâk şeklinde ihtisar edilen eserin Mahmûdü'l-Âlim el-Menzilî'nin (ö. 1311/1893) de Fükâhetü'l-ezvâk min Meşâri 'i'l-eşvâk adında bu eser üzerine bir muhtasarı bulunmaktadır. Bikâî de "Eşvâkü'l-eşvâkmim masâri 'ul uşşâk" adıyla bu eseri ihtisar etmiştir. ${ }^{103}$

51. el-Fîrûzâbâdî, Ebü’t-Tâhir Mecdüddîn Muhammed b. Ya‘kūb b. Muhammed (ö. 817/1415), Imtizâzü's-sehâd fi iftirâzi'l-cihâd. ${ }^{104}$

52. İbn Cemaâ, Ebû Abdillâh İzzüddîn Muhammed b. Ebî Bekr b. Abdilazîz elKinânî el-Hamevî (ö. 819/1416), Erbeûn hadisen fi'l-cihâd.

53. İbnü'l-Irâkī, Ebû Zürâ Veliyüddin Ahmed b. Abdürrahîm (ö. 826/1423), elErbâûn fì'l-cihâd bî dûni'l-isnâd. ${ }^{105}$

100 Bağdatlı İsmail Paşa, İ̇âh̆u'l-meknûn, 1/243; Ebû Gays Muhammed Hayrüddîn b. Mahmûd b. Muhammed b. Alî b. Fâris ez-Ziriklî, el-A 'lâm (b.y.: Dâru'l-İlmi'l-Melâyîn, 2002), 4/299. Eser, 2003 yılında Abdülilâh Nebhân ve Muhammed Fatih Zuğl tarafından tahkik edilerek neşredilmiştir (Abû Dâbî: Dâru'l-Bâverdî).

103 Ferhat Koca, “İbnü’n-Nehhâs ed-Dımaşkî", Türkiye Diyanet Vakfi İslâm Ansiklopedisi (İstanbul: TDV Yayınları, 2000), 21/176-177.

104 Kâtip Çelebî, Keşfü'z-zunûn, 1/167; Hediyetü'l-ârifîn'de eserin ismi İktizâzü'l-sehâd fî iftirâzi'lcihâd şeklinde geçmektedir. Bk. Bağdatlı İsmail Paşa, Hediyyetü'l- 'ârifîn, 2/181.

105 Bağdatlı İsmail Paşa, İ̇âḥu'l-meknûn, 1/54; Bağdatlı İsmail Paşa, Hediyyetü'l- 'ârifinn, 1/123. 
54. İbnü'l-Mürtezâ, el-Mehdî-Lidînillâh Ahmed b. Yahyâ b. el-Murtazâ (ö. 840/1437), el-Müstecâd fi şerhî kitâbi'l-i 'timâd li'l-âyâti'l-mu'tebere fi'lcihâd ${ }^{106}$, el-İntikâd li'l-âyâti'l-mutebere fî'l-cihâd. ${ }^{107}$

55. ed-Devâlibî, Afîfuddîn Alî b. Abdülmuhsin el- Bağdâdî el-Hanbelî (ö. 858/1454), el-İrşâd fî fâzli erbâbi'z-zikri ve'l-cihâd. ${ }^{108}$

56. el-Mahallî, Ebû Abdillâh Celâlüddîn Muhammed b. Ahmed b. Muhammed el-Ensârî (ö. 864/1459), Kitâb fi'l-cihâd. ${ }^{109}$

57. el-Bikâi, Ebû'l-Hasan Burhaneddîn İbrâhîm b. Ömer (ö. 885/1480), el-İsfâr ân eşrideti'l-esfâr. Kıbrıs ve Rodus'un fethi için 844 yılında çıkılan deniz seferinde telif edilmiş muhtasar bir eserdir. ${ }^{110}$ el-İstişhâd bi âyâti 'l-cihâd. ${ }^{111}$ 58. el-Melikü'l-Eşref, Ebû'Nâsr ez-Zahirî'l-Çerkezî (ö. 901/1496), Kitâbü'lfurûsiyye bî resmi'l-cihâd ve mâ e'de Allahü lil mücâhidîn mine 'l-ibâd ${ }^{112}$

59. es-Süyûtî, Ebü’l-Fâzl Celâlüddîn Abdurrahmân b. Ebî Bekr b. Muhammed el-Hudayrî eş-Şâfiî (ö. 911/1505), el-Erbaûn li’s-Süyûtîn ${ }^{13}$ veya Erbeîn fî fâzlili'lcihâd. ${ }^{114}$

60. Hâfâi, Nazâr b. Osman er-Rûmî (ö. 914/1508), Tuhfetü 's-seniyye fî fezâili'lcihâd. ${ }^{115}$

61. İbn Fehd el-Mekkî, Abdulaziz b. Ömer b. Muhammed (ö. 921/1515), etTerğ̂̉b ve'l-ictihâd fî̀'l-bâ 'is lî zevi'l-mühimi'l-iliyyeti âlâ'l-cihâd. ${ }^{116}$

106 Abdullah Muhammed el-Habeşî, Mesâdirü'l-fikri'l-İslâmî fi'l-Yemen (Beyrut: el-Mektebetü elAsriyye, 1408), 645.

107 Bağdatlı İsmail Paşa, Hediyyetü'l- 'ârifin, 1/125.

108 Kâtip Çelebî, Keşfü'zz-zunûn, 1/1; Ömer Rızâ Kehhâle, Mu 'cemü'l-mü'ellifìn, 7/142.

109 Ebü'l-Felâh Abdülhay b. Ahmed b. Muhammed el-Hanbelî İbnü'l-İmâd, Şezerâtü'zz-zeheb fì ahbâri men zeheb, thk. Mahmûd el-Arnâvûd (Beyrut-Dımaşk: Dâru İbn Kesîr, 1406), 9/448.

110 Kâtip Çelebî, Keş̧ü'z-ẓunûn, $1 / 81$.

111 Merkezü'l-Melik Faysal, Hizânetü 't-turâs (Suudi Arabistan: y.y., ts.), 43/284. Bu eser Merzuk Ali İbrâhim tarafindan Kahire, Menşurâtü Alâî Serhân; Dârü’r-Risâle'de 1423/2002 yılında neşredilmiştir.

112 Bağdatlı İsmail Paşa, Hediyyetü’l-ârifin, 1/834; Kehhâle, Mu'cemü'l-müellifin, 8/127.

113 Kâtip Çelebî, Keşfü'z-ẓunûn, 1/1.

114 Bağdatlı İsmail Paşa, Hediyyetü'l- ârifín, 1/535. Merzûk Ali İbrâhim'in tahkikiyle eser Kahire'de basılmıştır (Dârü'l-Fazile, ts.).

115 Bağdatlı İsmail Paşa, İżâhu'l-meknûn, 1/251; Bağdatlı İsmail Paşa, Hediyyetü'l- ârifîn, 2/495; Kehhâle, $M u^{\prime}$ 'cemü'l-mü' ellifin, 13/102.

116 Bağdatlı İsmail Paşa, İ̇âhu'l-meknûn, 1/283; Bağdatlı İsmail Paşa, Hediyyetü'l- ârifin, 1/583; Kehhâle, Mu'cemü’l-mü'ellifin, 5/255. 
62. Keşfî̀ Mehmed Çelebi (ö. 931/1525), Selimnâme-bâğ-ı fidevs-i gûzât ve râvzâ-i ehl-i cihâd. ${ }^{117}$

63. Molla Arab, Muhammed b. Ömer b. Hamza el-Antâkî el-Vâciz, (ö. 938/1531), es-Sedâd fi fâzli'l-cihâd. Eser, Sultan Selim'i cihadda kararlı kılmak için telif edilmiştir. ${ }^{118}$

64. el-Bekrî, Ebû'l-Hasen Tâcü'l-ârifîn Muhammed b. Muhammed b. Abdirrahmân es-Siddîkî (ö. 952/1545), Büşrâ'l- 'ibâd bî fâzli'r-ribât ve'lcihâd. ${ }^{119}$

65. Matrakçı Nasuh (ö. 971/1564), Tuhfetü'l-guzât fi fezâili'l-cihâd. Müellif tarafından çizilen resim ve krokilerin yer aldığı, savaş alet ve edavatının anlatıldığı bir eserdir. ${ }^{120}$

66. İkbal el-Kurtubî, Şerefüddin Ebü'l-Kasım b. Abdülalim b. Ebi'l-Kasım b. Osman Hanefî (974/1566), Kenzü'l-ibâd fi beyâni fezâili'l-gazv ve'l-cihâd. ${ }^{121}$

67. Nûreddinzâde, Filipeli Mustafa Muslihuddîn b. Nureddîn (ö. 981/1573), Fezâilü'l-cihâd. ${ }^{122}$

68. Ebüssuûd, Muhammed b. Muhammed Yavsi el-İmâdî (ö. 982/1574), Tehâfütü'l-emcâd fì evvelî kitâbi'l-cihâd mine'l-hidâye. Muhtelif konulara dair malumat veren eser özellikle cihad meydanın durumu üzerinde durulmuştur. ${ }^{123}$

117 Selimnâme, Yavuz Sultan Selim'in şahsını ve döneminde meydana gelen olayları ele alan eserlere verilen genel bir isimlendirmedir. Selimnâmeler üzerine yapılan bir bibliyografya çalışması için bk. M. C. Şehabeddin Tekindağ, "Selimnâmeler", İstanbul Üniversitesi Edebiyat Fakültesi Tarih Enstitüsü Dergisi 1 (Ekim 1970), 197-230; Konu hakkında yapılan iki yüksek lisans çalışması için ayrıca bk. Abdurrahman Sağırlı, Keşfi Mehmet Çelebi Selim-name veya Bă̆-ı Firdevs-i Guzat ve Ravza-i Ehl-i Cihad (İstanbul: İstanbul Üniversitesi, Sosyal Bilimler Enstitüsü, Yüksek Lisans Tezi, 1993); Şefaettin Severcan, Keşfi'nin Selimnâmesi (Kayseri: Erciyes Üniversitesi, Sosyal Bilimler Enstitüsü, Yüksek Lisans Tezi, 1988).

118 Kâtip Çelebî, Keşfü'z̧-žnûn, 2/982; Bağdatlı İsmail Paşa, Hediyyetü'l- 'ârifîn, 2/234; Kehhâle, Mu'cemü'l-mü'ellifin, 11/95.

119 Bağdatlı İsmail Paşa, İ̇âhư'l-meknûn, 1/184; Bağdatlı İsmail Paşa, Hediyyetü'l- 'ârifîn, 2/239.

120 Hüseyin Gazi Yurdaydın, "Matrakçı Nasuh", Türkiye Diyanet Vakfı İslâm Ansiklopedisi (Ankara: TDV Yayınları, 2003), 28/145.

121 Eser, 2010 yılında Yâsir Muhammed Yasin el-Bedrî el-Hüseynî tarafından tahkik edilerek neşredilmiştir (Beyrut: Dâru'l-Kütübi’l-İlmiyye, 2010).

122 Filipeli Mustafa Muslihuddîn Nûreddinzâde, Fezâilü'l-cihâd (İstanbul: Süleymaniye Kütüphanesi, Ayasofya, 1987), 1b-24b.

123 Kâtip Çelebî, Keşfü'z-zunûn, 1/509; İzâhü'l-mekûn'da, Nihâyetü'l-emcâd âlâ kitâbi'l-cihâd mine'lhidâye şeklinde geçmektedir. Bk. Bağdatlı İsmail Paşa, İżâhu'l-meknûn, 2/690; Hediyetü'l-ârifin'de ise Nihâyetü'l-emcâd 'âlâ'l-hidâye li’l-Merğinânî şeklinde geçmektedir. Bk. Bağdatlı İsmail Paşa, Hediyyetü'l- ârifin , 2/254; Osmanlı Müellifleri'nde ise Tehâfütü'l-emcâd fî evvelî kitâbi'l-cihâd 
69. el-Fâkihî, Abdülkadir b. Ahmed (ö. 982/1574), Menâhicü's-sürûr ve'r-reşâd fi'r-remy ve's-siyâk ve's-sayd ve'l-cihâd.

70. Vûsûlî, Muhammed b. Abdullah er-Rûmî (ö. 998/1590), Cihâdnâme-i Selim Hân. $^{124}$

71. el-Bosnevî, Ali b. El-Hâc Mustafa er-Rûmî el-Hanefî (ö. 1007/1598), Fezâilü'l-cihâd. ${ }^{125}$

72. Gelibolulu Mustafa Âlî (ö. 1008/1600), Mirkâtüll-cihâd fi tarihi melik danişmend ve evlâdihi. ${ }^{126} \mathrm{Bu}$ eser, hicri 997 yılında Danişmendoğluları zamanında yazılmış, Nâdirü'l-mehârib manzum türü bir çalışma olup Sultan Selim'in kardeşi Beyazıd ile savaşlarını anlatmaktadır. Esere belli aralıklarla ekleme ve çıkarmalar yapılmıştır. ${ }^{127}$

73. el-Hüseynî, Muhammed b. İbrahim (ö. 1019/1610), Zührü'l-mücâhidîn fî âdâb cihâdeddin ${ }^{128}$ veya Fezâilü'l-cihâd. ${ }^{129}$

74. el-Manâstırî, Mahmud b. Hayyât el-Hanefî (ö. 1026/1617), Fezâilü’lcihâd. ${ }^{130}$

75. el-Bursevî, Hüsâmeddin b. Halil (ö. 1042/1632), Fezâilü'l-cihâd. ${ }^{131}$

76. Es-Sicilmâsî, Abdülhâdî b. Abdullah b. Ali (ö. 1056/1646), Felekü s-saâde fi fâzli'l-cihâd ve'ş-şehâde.

şeklinde geçmektedir. Bk. Bursalı Mehmed Tâhir, Osmanlı Müellifleri, ed. Fikri Yavuz - İsmail Özen (İstanbul: Meral Yayınevi, ts.), 1/307.

124 Bağdatlı İsmail Paşa, Hediyyetü'l- 'ârifin , 2/259.

Bağdatlı İsmail Paşa, İ̇âhu'l-meknûn, 2/259; Bağdatlı İsmail Paşa, Hediyyetü'l- ârifiñ 1/495; Ömer Rızâ Kehhâle, Mu'cemü'l-mü'ellifin, 7/243; Hediyyetü'l-ârifin'de ölüm tarihi 1008/1600 olarak geçmekte, şair ve Rumeli kazaskeri olduğu bilgisi verilmektedir. Eser; İmâdü'l-cihâd, Fezâilü'lcihâd, Amâl-i fezâil-i cihâd adlarıyla da kaynaklarda yer almakatadır. Bk. Bursalı Mehmed Tâhir, "Fezâîl-i Cihâd Hakkında Müellefât-1 Osmâniyye" 2-9/46-228 (Kanunisani 1328), 347-348. Müellif ve eseri üzerine yapılan bir çalışma için bk. Nihal Türkmen (Çağman), Ali Dede Bosnevi Hayatı, Eserleri ve Fezai'lü'l-Cihad Adlı Eseri (İstanbul: Marmara Üniversitesi, Sosyal Bilimler Enstitüsü, Yüksek Lisans Tezi, 2019). Bağdatlı İsmail Paşa, Hediyyetü'l- 'ârifin, 2/438.

127 Kâtip Çelebî, Keş̧ü'z-zunûn, 2/1885.

128 Muhammed b. İbrahim el-Hüseynî, Zührü'l-mücâhidîn fî âdâb cihâdeddin (İstanbul: Süleymaniye Kütüphanesi, Lala İsmail, 61), 1a-54b.

129 Kehhâle, Mu'cemü'l-mü'ellifin, 8/197.

130 Bağdatlı İsmail Paşa, Hediyyetü'l- 'ârifìn, 2/414; Bursalı Mehmed Tâhir, Osmanlı Müellifleri, 1/373; Kehhâle, Mu 'cemü'l-mü'ellifin, 7/163. Hediyyetü'l-ârifin 'de eserin Şehid Ali Paşa Kütüphanesinde mevcut olduğu bilgisi verilmektedir.

131 Bağdatlı İsmail Paşa, İzâhu'l-meknûn, 2/196; Bağdatlı İsmail Paşa, Hediyyetü'l- 'ârifîn, 1/264; Bursalı Mehmed Tâhir, Osmanlı Müellifleri, 1/108; Kehhâle, Mu'cemü'l-mü' ellifin, 3/193. 
77. İbn Allân, Muhammed Ali b. Muhammed Allan el-Mekki el-Bekri, (ö. 1057/1648), Miftâhü'l-bilâd fi fezâili'l-gâzvi ve'l-cihâdlfì fezâili'l-gâzv ve'lcihâd. ${ }^{132}$

78. el-Konevî, Nuh b. Mustafâ (ö. 1070/1660), Fezâilü'l-cihâd. Eser, Meşâriü'luşşâk' 'n tercümesidir. ${ }^{133}$

79. el-Bâbelî, Şemsuddîn Ebû Abdullah Muhammed b. Alâuddîn Alî el- Kahirî el-Ezherî eş-Şâfiî (ö. 1077/1666), Kitâbü'l-cihâd. Müellif eseri Fazıl Ahmed Paşa için kaleme alınmıştır. ${ }^{134}$

80. Emir Mencek Paşa el-Yusûfî (ö. 1080/1669), el-İctihâd fî tâlebi'l-cihâd. ${ }^{135}$

81. Mustafa 'İz, Fâz1l İbn Muhsin ed-Dîn b. Muhammed (1091/1681), Târîkü’rreşâd fi'l-hâs alâ'l-cihâd. ${ }^{136}$

82. el-Hâc, Ramazan b. Mustafâ b. el-Vâli (ö. 1097/1692), Kenzü'l-ibâd fi fezâili'l-gâzv ve'l-cihâd. ${ }^{137}$

83. İbrâhîm b. Hasen el-Gûrânî, eş-Şîrâzî el- Kürdî (ö. 1101/1690), Meslekü'lirşâd, il'l-ehâdîsi'l-vâride fi'l-cihâd. ${ }^{138}$

84. el-Cevlânî, Muhammed Fikri b. Hüseyin (ö. 1104/1693), Mühimmâtü'l-gâzî fì meyâdini'l-megâzî. ${ }^{139}$

85. Muhammed Akîle el-Mekkî (ö.1150/1737), Fezâilü'l-cihâd. ${ }^{140}$

${ }_{132}$ Bağdatlı İsmail Paşa, İżâhu'l-meknûn, 2/523; Bağdatlı İsmail Paşa, Hediyyetü'l- 'ârifîn, 2/283. Bu eser Diyanet İslam Ansiklopedisi'nde müellifin eserleri arasında verilmemiştir. Bk. Sâmî es-Sakkâr, “İbn Allân”, Türkiye Diyanet Vakfi Íslâm Ansiklopedisi (İstanbul: TDV Yayınları, 1999), 19/307-308.

133 Bursalı Mehmed Tâhir, Osmanlı Müellifleri, 1/416; Müellifi ve eserlerini konu edinen bir çalışma için bk. Hayati Yılmaz, "Nûh b. Mustafa el-Konevî’nin er-Risâle fi'l-Fark Beyne'l-Hadîsi'l-Kudsî ve'lKur'ân ve'l-Hadîsi'n-Nebevî Adlı Risâlesi”, Hadis Tetkikleri Dergisi 1/1 (2003), 167-170.

134 Bağdatlı İsmail Paşa, Hediyyetü'l- 'ârifîn, 2/290; Kehhâle, Mu 'cemü'l-mü'ellifin, 11/34. Hizânetü'tturâs'ta yazma nüsha kaydı olarak eserin ismi Risâle fi'l-cihâd ve'l-fezâilihi, Fezâilü'l-cihâd şeklinde geçmektedir. Bk. Merkezü'l-Melik Faysal, Hizânetü't-turâs, 46/860.

Bağdatlı İsmail Paşa, İżạhu'l-meknûn, 1/26. Eserin müellifi hakkında yapılan müstakil bir çalışma için bk. Recai Kızıltunç, “Arap Edebiyatında Türkçe Yazan Bir Şair: Emir Mencek Paşa el-Yusûfı̂”, $\dot{I}$. $\ddot{U}$. Şarkiyat Mecmuası 20 (Ocak 2012), 33-48. Kehhâle, Mu'cemü'l-mü'ellifin, 12/265.

137 Kehhâle, $M u$ 'cemü'l-mü'ellifin, 4/172.

138 Kehhâle, $M u$ 'cemü'l-mü' ellifin, 1/21.

139 Bu eser 1284/1867 yılında İstanbul Matbaa-i Âmire’de neşredilmiştir.

140 Selahattin Yıldırım, "XIX. Yüzyıl Osmanlı Muhaddisleri ve Eserleri”, Din Eğitimi Araştırmaları Dergisi 13 (2004), 274. 
86. el-Berzencî, Abdullâh Hasan (ö. 1156/1743), el-Menhecü's-sedâd ilâ efdâli'lcihâd. ${ }^{141}$

87. Mîrzâzâde Mehmed Sâlim Efendi, Muhammed Emin b. Mirza Mustafa elKādî er-Rûmî el Bâtûmî (ö. 1156/1743), Neylü'r-reşâd fì em-ri'l-cihâd. ${ }^{142}$

88. Gazzâl el-Fâsi, Ahmed b. Sehl el-Endûlîsî (ö. 1179/1765 civarlarında), Netîcetü'l-ictihâd fî'l-muhâdeneti ve'l-ictihâd. ${ }^{143}$

89. Ömer el-Fâsî, Ebû Hafs Ömer b. Abdullah b. Ömer el-Fehrî (ö. 1188/1774), Cevab suâl fi'l-cihâd.

90. Hanîf İbrahim Efendi (ö. 1189/1775), Sehmü'l-isâbe fî fezâili'r-remy ve’ssihâm. $^{144}$

91. ez-Zimârî, Kadı Abdülkadir b. Muhammed b. Hüseyn (ö. 1197/1783), enNâzmü'l-müstecâd fi'l-hâs alâ'l-cihâd.

92. Râzî er-Rûmî, Mustafâ b. el-Kostântînîvî (ö. 1198/1784), Gâzâvâtnâme-i Türkîfì'l-cihâd. ${ }^{145}$

93. Küttâbî, Hasan b. Muhammed el-Misrî (ö. 1211/1796' dan sonra), Fezâilü'lcihâd ${ }^{146}$ veya Delâilü'n-nâsr ve'l-fütuhât min fezâili'l-cihâd ân seyyid.

94. Ahmed b. Yunus, Tefsirü erba'âti âyât min sureti't-tevbe fì'l-cihâd.

95. Ahmed Fehmi Efendi, Tuhfetü'l-guzât fí fezâili'l-cihâd. ${ }^{147}$

96. Ahmed el-Hanyâvî, Tâhrîzü'l-mücâhiddîn fi sebilillâh.

97. Ali b. Muhammed, Zâdü'l-cihâd. ${ }^{148}$

141 Abdullâh Hasan el-Berzencî, el-Menhecü's-sedâd ilâ efdâli'l-cihâd (İstanbul: Süleymaniye Kütüphanesi, Laleli, 3680), 61a-74b.

142 Bağdatlı İsmail Paşa, Hediyyetü'l- 'ârifin, 2/325; Kehhâle, Mu 'cemü'l-mü' ellifin, 10/17.

143 Bağdatlı İsmail Paşa, Îżâhu'l-meknûn, 2/622; Bağdatlı İsmail Paşa, Hediyyetü'l- 'ârifîn, 1/176; Kehhâle, Mu'cemü'l-mü'ellifin, 2/186; 8/40. Eser, İsmail Arabî tarafindan Neticetü'l-ictihad fi'lmuhâdene ve'l-cihâd: rihletü'l-gazzâl ve sefaretehu ile'l-Endelüs adiyla Beyrut Dârü'l-Garbi'lİslâmî'de 1980 yılında tahkik edilerek neşredilmiştir.

144 Cemil Akpınar, "Hanîf İbrahim Efendi", Türkiye Diyanet Vakfi İslâm Ansiklopedisi (İstanbul: TDV Yayınları, 1997), 16/41.

145 Bağdatlı İsmail Paşa, Hediyyetü'l- 'ârifîn, 2/453. Gazavâtnâmeler üzerine yapılan bir çalışma için bk. Kürşat Şamil Şahin, "Gazavâtnâmeler Üzerine Yapılan Çalışmalar Hakkında Bir Bibliyografya Denemesi”, Turkish Studies 7/2 (2012), 997-1022.

146 Kehhâle, Mu 'cemü'l-mü' ellifin , 3/295.

147 Hakan Yılmaz, "Tarihten Sayfalar: Murâd Hüdâvendigâr Adına Yazılmış Bir Eser: Tuhfetü'l-Guzât fî Fezâ'ili'l-Cihâd”, Hakikat Dergisi 198 (Mart 2010).

148 Bağdatlı İsmail Paşa, Îżâhu'l-meknûn, 1/605. 
98. el-Asârî, İbnü'l-Vaiz Muhammed b. Yusuf el-Kayseri, el-İctihâd fi fâzli'lcihâd.

99. Çuhadar, Ahmet b. el-Hac Muhammed, Tâ'lim-i cihâd.

100. Derviş Ali b. Mustafâ, İmâdü'l-cihâd.

101. ed-Dımaşkî, Seyyid Muhammed Arif, el-î'timâd fî̀'l-cihâd. ${ }^{149}$

102. Ebü'l-Berekât, Hafiz Ahmed Fahreddîn, İşâdü'l-ibâd ilâ izzeti'l-cihâd. ${ }^{150}$

103. el-Gâzzî, Muhammed b. İbrâhîm, et-Turûku's-sedâd fi fâzli'l-ümerâ ve'l-cihâd.

104. İbn Hamid, Abdülevvel b. Hüseyin b. Hasan, el-Hâmsûn fi tevârihi cihâdi’ssultan ma'a'l-mücâhidîn.

105. İbn Salâh, Abdullâh b. Salah b. Davûd b. Alî, Fütuhâtü'l-muradiye fi'l-cihâdi'lYemeniyye.

106. el-Karâfî, Nureddîn Ebû'l-Hasan Ali b. Ahmed el-Ensarî, Erbâûn hadisen $f i$ fâzli'l-cihâd, Sübûlü'r-reşâd fi fâzli'l-cihâd.

107. el-Kârşî, Şeyh Ebû Said Şaban b. Muhammed el- Musilî, el-Menhelü'l- 'azb li vürûdî ehli'l-hârb. ${ }^{151}$

108. Muhammed b. Ömer b. Keykeldî, Mesîrü ehlî saâde ilâ irtikâî derecâtî’şşehâde. Eser, âlimlerin, hukemânın cihad mevzusunda serd ettikleri sözlerini ele almaktadir. ${ }^{152}$

109. Musa el-Halebî, Yahyâ b. Şeyhülislâm, Bezlü's-suhâd fi fâzli'l-cihâd.

110. Serezli Mustafa, Tercüme-i şerhi hadisü'l-erbâîn fi terğibü'l-cihâd.

111. es-Sıddıkî, Alî b. Muhammed, Zâdü'l-cihâd ve necâtü'l-ecnâd.

112. Şair Derviş Ahmed Kermeyâni, Cenknâme. Sultan Selim'in kardeşi Beyazıd ile yaptığı savaşı anlatmaktadır. ${ }^{153}$

113. et-Tirhalâvî, Alaüddin Kâmili, el-Fusûlüll-erbâûn fî usûlî cihâdi'd-din.

114. el-Yafîi, Ebü'n-Nasr Muhammed Mansûr el-Hanefî, Hidâyetü'l-ibâd fi fezâili'lcihâd.

149 Bağdatlı İsmail Paşa, İżạhu'l-meknûn, 1/98.

150 Bu eser İstanbul'da Matbaa-i Amire'nin birinci sayısında basılmıştır.

151 Kâtip Çelebî, Keş̧ü'z-zunûn, 2/1885.

152 Kâtip Çelebî, Keş̧ü'z-z̧unûn, 2/1686.

153 Kâtip Çelebî, Keş̧ü'z-żunûn, 1/607. 


\subsubsection{Risaleler}

1. İbnü'l-Arabî, Ebû Bekr Muhammed b. Abdillâh b. Muhammed el-Meâfirî (ö. 543/1148), Risale fi'l-cihâd.

2. İbn Hacer el-Askalânî, Ebü'l-Fâzl Şihâbüddîn Ahmed b. Alî b. Muhammed (ö. 852/1449), Risale fi'l-ehâdisi'l-cihâd. ${ }^{154}$

3. Hatipzâde, Muhyiddin Muhammed b. İbrahim el-Kastamonî (ö. 901/1496), Fezâilü'l-cihâd. ${ }^{155}$

4. İbn Mibred el-Hanbelî, Cemâleddin Yusuf b. Hasan İbn Abdü'l-Hâdî (ö. 909/1503), Risale fi'r-remh ve'l-âlâti'l-cihâd.

5. Mustafâ b. el-Hac Hasan (ö. 911/1505), Risale fi fevâidi'l-cihâd.

6. el-Kirmâstî, Yusuf b. Hüseyin (ö. 920/1514), Risâle fì'l-cihâd, Risâle fî fezâili'l-cihâd. ${ }^{156}$

7. Muhyiddin Muhammed b. Bahaeddîn (ö. 956/1549), Risale fi'l-cihâd.

8. Mirem Kûsesî, Muhammed Çelebi b. Muhammed (ö. 957/1551), Risâle fi'lcihâd.

9. İmam Birgivî (ö. 981/1573), Risale-i cihâdiye.

10. Ali el-Kârî, Ebü'l-Hasen Nûrüddîn (ö. 1014/1605), Risale-i cihâdiyye li'nnefs.

11. Kadı Mahmûd b. Ahmed b. Muhammed (Manastirî Terzizâde) (ö. 1126/1714), Risale fi fezâili'l-cihâd. ${ }^{157}$

154 Bu eser İsam Türkiye Kütüphaneleri Veri Tabanında İbn Hacer’e atfedilmemiştir. Kaynaklarda verilen ölüm tarihin İbn Hacer'inkiyle uyuşması ve risalenin hadis alanında kaleme alınmış olmasından ötürü bu eserin ona ait olabileceği kanaatine vardık.

Kâtip Çelebî, Keşfü'z-zunûn, 1/859. Risale muhtelif isimlerle anılmıştır: Risale fi hakki'l-cihâd, elİşâd fî fezâili'l-cihâd, Risâle fi'l-cihâd. Bk. İlyas Üzüm, "Hatibzâde Muhyiddin Efendi", Türkiye Diyanet Vakfi İslâm Ansiklopedisi (İstanbul: TDV Yayınları, 1997), 16/463-464.

156 Kâtip Çelebî, Keşfü'ż-zunûn, 1/859. Hediyyetü'l-ârifîn'de müellifin ölüm tarihi 906 olarak verilmiştir. Bk. Bağdatlı İsmail Paşa, Hediyyetü'l- 'ârifîn, 2/563; Diyanet İslam Ansiklopedisi'nde ise Şekâîk'in verdiği tarih esas alınmıştır. Bk. Ahmet Özel, "Kirmâstı̂”, Türkiye Diyanet Vakfi İslâm Ansiklopedisi (Ankara: TDV Yayınları, 2002), 26/67-68. Fakat biz burada Osmanlı Müellifleri'nde geçen tarihi esas aldık. Bk. Bursalı Mehmed Tâhir, Osmanlı Müellifleri, 1/464.

Bursalı Mehmed Tâhir, Osmanlı Müellifleri, 1/373. 
12. en-Nâblusî, Abdülgânî b. İsmâîl b. Abdilganî b. İsmâîl (ö. 1143/1731), Risâletün fî'l-hâs 'âlâ'l-cihâd, ${ }^{158}$ Beyânü'l-cihâd li ehli'l-vedâd.

13. Osman Kırımî Enderûnî (ö. 1149/1736), Icâletü’s-defer ve risaletü'z-zafer.

14. Veliyyüddin Cârullâh, Ebû Abdullah b. Mustafa b. Ali el-İstanbulî, (ö. 1151/1738), Risâle-i cihâd-ı kebîr- fezâilü'l-cihâd. ${ }^{159}$ Eser müellif tarafından Gazi Ali Paşa'ya takdim edilmiştir. ${ }^{160}$

15. ed-Dârendî, Muhammed b. Ömer b. Osman (ö. 1152/1739), Risâle fî'l-cihâd. Risâlenin tam adı bilinmemektedir. Bağdatlı İsmail Paşa eserin cihad ve gâzve konularını incelediğini ve Sultan III. Ahmet için kaleme alındığı ifade etmektedir. ${ }^{161}$

16. İbn Ebî İshâk, Muhammed b. Şeyhülislâm Ebâ İshâk İsmail b. İbrahim erRûmî (ö. 1166/1753), Nesriyetün fî'l-cihâd. Sultan I. Mahmud için Türkçe olarak yazılmış bir risaledir. ${ }^{162}$

17. Müfti Ahmed Hifzî Efendi (ö. 1181/1768), Nehcü'r-reşâd fì emri'l-cihâd. ${ }^{163}$

18. Emîr es-San‘ânî, Ebû İbrâhîm İzzüddîn Muhammed b. el-İmâm elMütevekkil-Alallâh İsmâîl (ö. 1182/1768), Risâle fi'l-hâss alâ'l-cihâd.

19. el-Aydınî, Kadı Mustafa el-Urlâvi, Risaletü'l- cihâdiyye, ${ }^{164}$ Tercüme-i risalei cihâdiyye.

20. el-Hâlebî, Ebü'l-Maâlî el-Haddâd, Risaletü'l-cihâdiye.

21. Nurullâh b. Abdullâh, Risale fi beyânî sebebi takdimi'n-nikâhi âla kitâbi'lcihâd.

158 Bağdatlı İsmail Paşa, Hediyyetü'l- ârifin, 1/594. Eser Hizânetü't-Turâs'ta Risâle fi'l-cihâd şeklinde geçmektedir. Bk. Merkezü'l-Melik Faysal, Hizânetü̈t-turâs, 22/ 976. Tahsin Özcan, "Veliyyüddin Cârullah", Türkiye Diyanet Vakfi İslâm Ansiklopedisi (Istanbul: TDV Yayınları, 2013), 43/39.

161 Bağdatlı İsmail Paşa, Hediyyetü'l- 'ârifin, 2/324.

162 Bağdatlı İsmail Paşa, Hediyyetü'l- 'ârifin , 2/329.

163 Bursalı Mehmed Tâhir, "Fezâill-i Cihâd Hakkında Müellefât-ı Osmâniyye”, 347-348. Eser matbu olup 1295/1878 yılında İstanbul Ceride-i Askeriyye Matbaasında yayınlamıştır.

164 Bursalı Mehmed Tâhir, Osmanlı Müellifleri, 1/373. 


\subsection{Sömürgecilik Sonrasında ve Modern Dönemde Yazılan Eserler}

\subsubsection{Kitaplar}

1. Ayıntâbî, Mehmed Münîb (ö. 1234/1819), Fezâilü'l-cihâd, ${ }^{165}$ el-Hikmetü'lgarrâ'fí ahkâmi'l-gazâa. ${ }^{166}$

2. Şânîzâde Mehmed Atâullah Efendi (1242/1826), el-Cihâdiye, ${ }^{167}$ Tedbîrü'lmemâlik ve'l-cihâd/ Kavânînü'l-asâkiri'l-cihâdiyye. ${ }^{168}$

3. Tabâtabâî, Yusuf b. Abdülfettah b. Atâ (ö. 1242/1826), el-Cihâdiyye fî'l-hâzzi âlâ'l-cihâd. ${ }^{169}$

4. Abdullâh er-Rûmî (1252/1836), Tezkiratü'r-rumât. ${ }^{170}$

5. Darıcalı Pertev Paşa (ö. 1253/1837), Lâyıhâ-i ittihâdiye. Müellif eserde, Osmanlının son dönemlerinde yaşamış olduğu bozgun ve kuşatmaların müslümanların işlediği kötülük ve günahlardan kaynaklandığını ifade etmekte, bu durumun önüne geçmenin en önemli yolunun da ümmet olarak cihada sarılmakta olduğunu salık vermektedir. ${ }^{171}$

6. Sahaflar Şeyhizâde Esad Efendi (1264/1848), Kevkebü'l-mesûd fî kevkebeti'lcünûd, Risâletü'l-Cihâdiye, Türkçe yazılmış bir risaledir. ${ }^{172}$ Tercüme-i fezâili cihât. ${ }^{173}$

7. el-Umrâvî, Muhammed b. İdrîs b. Muhammed (ö. 1264/1848), Kâside dâliyye fi'l-cihâd.

165 Bağdatlı İsmail Paşa, Hediyyetü'l- ârifîn, 2/360; Bursalı Mehmed Tâhir, Osmanlı Müellifleri, 1/407; Kehhâle, Mu'cemü'l-mü'ellifin, 11/257. Mehmet Tahir, Fezâilü'l-cihâd'ın aslında el-Hikmetü'lgarrâ' fi ahkâmi'l-gazâ ile aynı eser olduğunu belirtmiştir. Fakat Kehhâle ve İsmail Paşa ise her iki çalışmanın müstakil birer eser olduğunu ifade etmişlerdir. Diyanet İslam Ansiklopedisi'nde ölüm y1lı 1823 olarak verilmiştir. Bk. Özel, “Ayıntâbî”, 4/245-246.

166 Yıldırım, "XIX. Yüzyıl Osmanlı Muhaddisleri ve Eserleri”, 74. Muhammed Akîle el-Mekkî’nin (ö.1150/1737) Fezâilü'l-cihâd eserinin tercümesidir. a.g.e., aynı yer.

167 Bağdatlı İsmail Paşa, Hediyyetü'l- 'ârifinn, 2/363.

$168 \mathrm{Bu}$ eser muhtemelen müellifin el-Cihâdiye eserinin bir başka adlandırmasıdır. Bulak Matbaası'nda 1221 'de basılmıştır.

169 Kehhâle, Mu'cemü'l-mü'ellifin, 13/310.

170 Yıldırım, “XIX. Yüzyıl Osmanlı Muhaddisleri ve Eserleri”, 281-282.

171 Orhan M. Çolak, “İstanbul Kütüphanelerinde Bulunan Siyasetnâmeler Bibliyografyası”, Türkiye Araştırmaları Literatür Dergisi 1/2 (2003), 24.

172 Bağdatlı İsmail Paşa, Hediyyetü'l- ârifin, 2/372.

173 Yaptığımız araştırmalar neticesinde müellifin böyle bir eseri tespit edilememiştir. Bu eserin müellifin yukarıda verilen tercüme eserinin bir başka isimlendirmesi olduğu kanaatine ulaşılmıştır. 
8. Hasan el-Baytârî, Hasan b. İbrahim b. Hasan en-Nakşibendî el Meydânî (ö. 1272/1856) İrşâdül-ibad fi fâzli'l-cihâd. ${ }^{174}$

9. el-Kostendîlî, Muhammed Şem“i b. Abdullah el-Rûmî (ö. 1272/1885), Râyâtü'n-nâsr ve'l-irşâd fí fezâili'l-cihâd. ${ }^{175}$ Müelif, 1853 'te Ruslarla yapılan savaşta üstün gelinmesi ve halkın cihada teşvik edilmesi amacıyla eserini kaleme almış ve Sultan Abdülmecit'e ithaf etmiştir. ${ }^{176}$

10. el-Ayıntâbî, Mustafa Saîd b. Muhammed b. Muhammed el-Hanefî̀ (ö. 1279/1902), Cihâdiye, fezâilü'l-cihâd türü bir eserdir. ${ }^{177}$

11. el-Kayserî, Muhammed b. Hüseyin b. Ramazân (ö. 1280/1863), Zübdetü'lmurâd fì emri'l-cihâd. ${ }^{178}$

12. Milas Müftüsü Durmuşzâde Hafız Mustafa Sadık (ö. 1280/1863), Alem-i İslâm cihâd-ı ekber. ${ }^{179}$

13. Ahdâb er-Rammâh, Necmeddin Eyyûb (ö. 1295/1877), Kitâbü'l-furûsiyeti fi resmi'l-cihâd, ${ }^{180}$ el-Gâzv ve'l-cihâd.

14. el-Bağdâdî, Seyyid Davud b. Süleyman en-Nakşibendî el-Hâlidî (İbn Circîs)

(ö. 1299/1882), Eşeddü'l-cihâd fi ibtâli dâ've'l-ictihâd. ${ }^{181}$

15. el-İdrisî, Muhammed b. Abdülkâdir b. Osman (ö. h. 13. y.y.), Şerhu yetîmeti'l-ciyâd fi's-sâfinâti'l-mu 'ideti'l-cihâd.

16. Zeynî Dahlân, Ahmed b. Zeynî b. Ahmed (ö. 1304/1886), İşâdü'l-ibâd fi fezâili'l-cihâd.

17. el-Berzencî, Şeyh Kâkâ Ahmed b. Muhammed (ö. 1305/1888), Fethü'lcevâd fì beyâni'l-cihâd. ${ }^{182}$

$\overline{174}$ Kehhâle, Mu'cemü'l-mü'ellifîn, 3/194. Eser Muhammed b. Nasr el-Acmî tarafindan 1421/2000 yılında Beyrut'ta tahkik edilerek yayınlanmıştır.

175 Bağdatlı İsmail Paşa, İ̇âhu 'l-meknûn, 1/547; Bağdatlı İsmail Paşa, Hediyyetü 'l- ârifîn, 2/374; Bursalı Mehmed Tâhir, Osmanlı Müellifleri, 1/450.

176 Bursalı Mehmed Tâhir, Osmanlı Müellifleri, 1/450; Yıldırım, “XIX. Yüzyıl Osmanlı Muhaddisleri ve Eserleri”, 285.

177 Bağdatlı İsmail Paşa, Hediyyetü 'l- 'ârifinn, 2/458; Bursalı Mehmed Tâhir, Osmanlı Müellifleri, 1/381. Müellifin Osmanlı Müellifleri eserinde Kâtip Mustafa Efendi (Kürdzâde) künyesiyle geçmektedir.

178 Kehhâle, Mu 'cemü'l-mü'ellifin, 9/240.

179 Eser, 1924 yılında İstanbul Matbaa-ı Amidî’de yayınlamıştır.

180 Eser, Mektebetü'l-Vataniyye'de basılmıştır.

181 Bağdatlı İsmail Paşa, Hediyyetü'l- 'ârifín, 1/363. 
18. Gümüşhaneli Hacı Ahmed Ziyâeddîn Efendi (ö. 1311/1893), Fezâilü'lcihâd. ${ }^{183}$ Kitâbu'l-'âbir fi'l-ensâri ve'l-muhâcir ve'l-cihâdi ve'l-gazvi ve'şşühedâi me'a ahkâmihâ ve hakâikihâ ve dekâikihâ ve tefâsîrihâ ve envâ' 'hâ ve fezâilihâ. Cihad ve hicret konularının âyet ve hadisler ışığında tasavufî bir yaklaşımla ele alındığı bir eserdir. ${ }^{184}$

19. el-Menzilî, Mahmûd b. Ömer (ö. 1311/1893), Fukâhetü'l-ezvâk min meşâri 'i’l-eşvâk. ${ }^{185}$

20. er-Raşidî, Said b. Hammad b. Amir b. Hâlfaân (ö. 1314/1897), Lâmiyetün fî'd-difâ' 've'l-cihâd. ${ }^{186}$

21. en-Nazililî, Muhammed Hakk1 Efendi (ö. 1315/1897), Nusrâtü’l-cunûd ani'ş-şuhûd/ umdetu'ş-şuhûd/ ve'l-ehâdîsi'l-vâride fî'l-cihâd ve mâ eşbehe zâlik. $^{187}$

22. Edirne Müftüsü Kureyşizâde Mehmed Fevzi Efendi (ö. 1318/1900), Seyfü'lcihâd fi nâsri'l-îbâd. ${ }^{188}$

23. Mehmed Halis Efendi (ö. 1332/1913), Cihâd-ı ekber. ${ }^{189}$

24. Dinibütün Mustafa Hilmi Paşa (ö. 1333/1914), Düstürü'l-mücahidîn.

Cihadın faziletini konu edinen bir eserdir. ${ }^{190}$

182 Bağdatlı İsmail Paşa, Tżâhu 'l-meknûn, 2/161; Bağdatlı İsmail Paşa, Hediyyetü'l- 'ârifîn, 1/192; Bursalı Mehmed Tâhir, Osmanlı Müellifleri, 1/146; Kehhâle, Mu'cemü'l-mü'ellifin, 2/158.

183 Bursalı Mehmed Tâhir, Osmanlı Müellifleri, 1/102.

184 Eserin tercüme ve tahrici için bk. Ahmed Ziyâüddîn Gümüşhânevî, "Ensar, Muhacir, Cihâd, Gazve ve Şehitler Hakkında", çev. Ömer Faruk Habergetiren, Tarih Kültür ve Sanat Araştırmaları Dergisi 2/4 (2013), 232-269.

185 Bağdatlı İsmail Paşa, İ̇âhu'l-meknûn, 2/200; Bağdatlı İsmail Paşa, Hediyyetü'l- ârifîn, 2/422; Kehhâle, Mu'cemü'l-mü'ellifin, 12/172. Eserin ismi Hediyyetü'l-'ârifin'de Fukâhetü'l-ezvâk min meşâri 'i' 'l-eşvâk fí fezâili'l-cihâd şeklinde geçmektedir. Matbu nüshası 1290/1873'te Mısır'da elMatbaâtü's-seniyyetü'l-kübrâ tarafindan Fukâhetü 'l-ezvâk min meşâri 'i' 'l-eşvâk fí fâzli'l-cihâd ve'ttarğ̂̀b fihi ve'l-hâss âleyhi adıyla neşredilmiştir.

186 Kehhâle, Mu'cemü'l-mü' ellifin, 4/222.

187 Bağdatlı İsmail Paşa, İzâhhu'l-meknûn, I2/651; Bağdatlı İsmail Paşa, Hediyyetü'l- ârifîn, 2/384; Bursalı Mehmed Tâhir, Osmanlı Müellifleri, 1/113.

188 Eser, İstanbul Yahya Efendi Matbaası'nda 1294/1877 yılında basılmıştır. Ayrıca bk. Mustafa İsmet Uzun, "Fevzi Efendi", Türkiye Diyanet Vakfi İslâm Ansiklopedisi (Ankara: TDV Yayınları, 1995), $12 / 508$.

189 Eser, Kanaat Matbaası tarafindan 1333/1914 yılında İstanbul'da yayınlamıştır. Bk. Hakkı Maviş, "Mehmed Hâlis Efendi", Türkiye Diyanet Vakfi İslâm Ansiklopedisi (Ankara: TDV Yayınları, 2003), $28 / 490$.

190 Bağdatlı İsmail Paşa, İżạhu'l-meknûn, 1/472. Eser Şehzade Yusuf İzzeddin Efendi için yazılmış olup 1292/1875'te İstanbul'da basılmıştır. 
25. Divrikli Ahmed Mikdad Efendi (ö. 1923/1939), Şerefü'l-mücâhidîn. ${ }^{191}$

26. Kemahlı İbrâhim Hakkı Efendi (ö. 1859/1924), Tâcü'l-mücahidîn mine'lehadisi'l-erbain, Tuhfetü'r-reşâd fî fezâili'l-cihâd. ${ }^{192}$

27. el-Mevsilî, Ahmed Fahri b. Abdullâh el-Feyzizâde (ö. 1342/1924?), İşâdü'libâd ile'l-gâzv ve'l-cihâd. ${ }^{193}$

28. el-Bilimbânî, Abdülsâmed el-Câvî, Nasihatü'l-müslimîn ve tezkiretü'lmü 'minîn fi fezâili'l-cihâd fi sebîlillâh ve kerâmâti'l-mücâhidîn.

29. el-Îsâvî, Muhammed b. Muhammed, Tenbîhü'l-ibâd bi ba'di ma verede fi fâzli'l-cihâd mine'l-âyât ve'l-ehâdîs.

30. İzzet el-Hac Hâfız, Mevâizü'l-cihâd ve'd-din li asâkiri'l-muvahhidîn.

31. Muhammed Garnîd, Manzume fi'l-hâs alâ'l-cihâd.

32. Mübârekşâh, Ali b. Mehmed b. Abdülmelik b. Ali, Miftâhü'l-bilâd fí fezâili'lgürz-i ve'l-cihâd.

33. Nureddîn Alî el-Mekkî, Tevtietü'l-mehâd fî fâzli'l-cihâd. ${ }^{194}$

34. Turhala'lı Alâeddin Kâmili Efendi, Ucale-i fusûl-i erbâin fi usûli'd-dîn.

Cihadın faziletini konu edinen bir eserdir. ${ }^{195}$

35. Ahmed Fahruddin Efendi, İşâdü'l-ibâd ile'l-gazvi ve'l-cihâd, İstanbul: Matbaa-i Âmire, 1917, 250, s. 6.

36. Ahmed Ziyaeddin, Vesiletü'n-Necât: İtikâd ve 'Amel ve Cihada Müteallik Hayli Mesâil-i Mühimme-i Diniyyeyi Hâvidir, Dersaâdet: Selânik Matbaas1, 1911/1327.

37. Ali Galib, Kitâb-ı fezâil-i gazâ: Menâkıb-i cihâd, Dersaâdet: Tevsi-i T1baât Matbaas1, 1330.

38. Bekir S1dk1, Mev'ıza-i tahrîriye der hâkk-ı cihâd-ı Íslâmiye ve tedâbir-i maneviyat, Dersaâdet: Matbaâ-i Kader, 1331.

191 Eser Dersaadet’te Necm-i İstikbâl Matbaası tarafından 1331/1912 yılında basılmıştır.

192 Bk. Ali Birinci, “Kemahlı Şeyh İbrahim Hakkı'nın Serencamı”, Türk Yurdu 110 (1996), 3-7; Selami Şimşek, “Erzincan Mevlevîhânesi Son Postnişini Kemahlı İbrahim Hakkı Efendi’nin Dîvân'ında Mevlânâ ve Mevlevîlikle İlgili Düşünceleri”, Tasavvuf: İlmî ve Akademik Araştırma Dergisi 8/20 (2007), 165.

193 Eser Matbaa-i Amire’de 1336 senesinde basılmıştır.

194 Bağdatlı İsmail Paşa, Hediyyetü'l- 'ârifin, 1/339.

195 Bursalı Mehmed Tâhir, Osmanlı Müellifleri, 1/450. 
39. İzzet, el-Hac Hafiz, Mevâizüll-cihâd ve'd-din li-âsâkiri'lmuvahhidîn, İstanbul: Matbaa-i Askeriye, 1331.

\subsubsection{Risaleler}

1. Hâtûnâbâdî, Muhammed b. Hüseyin es-Sâğîr b. Abdülbâkî (ö. 1233/1817), erRisâletü'l-cihâdiyye. ${ }^{196}$

2. Gazzîzzâde, Seyyid Abdüllatîf b. Mehmed Es'ad el-Hafid (ö. 1247/1832), Risâletü'l-cihâd. ${ }^{197}$

3. Sahaflar Şeyhizâde Esad Efendi (1264/1848), Risâletü'l-cihâdiye. Müellif bu eseri Türkçe kaleme almıştır. ${ }^{198}$

4. Âlûsî, Ebü's-Senâ Şihâbüddîn Mahmûd b. Abdillâh b. Mahmûd el-Hüseynî (ö. 1270/1854), Sufrâtü'z-zâd fì sefrâti'l-cihâd. Cihadın faziletini anlatan bir risaledir. ${ }^{199}$

5. el-Lâzikî, Abdurrezzâk b. Seyyid Abdulfettâh, Teşvikât'ül-ciyâd fi'l-gâzvi ve'lcihâd. Müellif, 1270’te Halep valisiyken bu eseri kalme almıştır. ${ }^{200}$

6. Uleyş, Ebû Abdullâh Muhammed b. Ahmed b. Muhammed (ö. 1299/1882), Risale fi vucûbi'l-cihâd ve'l-hicre.

7. el-Eskişehrî, Süleymân Hakkı b. Muhammed Emin b. Süleymân (ö. 1315/1897), Umdetü'l-cihâd. ${ }^{201}$

8. Oflu Mehmed Emin Efendi (ö. 1329-20/1902), Risâle-i cihâd. ${ }^{202}$

9. Muhammed el-Cerrâh, Muhammed Edîp en-Nakşibendî el-Hanefî (ö. 1336/1918), Risâletü'l-cihâd âlâ fetvâ hâlifetünâ'l-e'zâm es-sultan el-gâzi Muhammed Reşâd. ${ }^{203}$

196 Kehhâle, $M u$ 'cemü'l-mü'ellifin, 9/241.

197 Bağdatlı İsmail Paşa, Hediyyetü'l- 'ârifîn, 1/618; Bursalı Mehmed Tâhir, Osmanlı Müellifleri, 1/102. Ramazan Önal, müellif hakkında yazdığı makalesinde müellifin Nüshası Tespit Edilemeyen Eserleri arasında bu risaleye de yer vermektedir. Bk. Önal, Gazzîzâde Abdüllatîf Efendi'nin Fütuhâtu Kenzi'lKur'ân Adlı Fâtiha Sûresi Tefsîrinin Tahlili ve Değerlendirilmesi, 43.

Bağdatlı İsmail Paşa, İzâhu'l-meknûn, 2/372. Bağdatlı İsmail Paşa, İżâhu'l-meknûn, 1/292; Bağdatlı İsmail Paşa, Hediyyetü'l- 'ârifìn, 1/568; Kehhâle, Mu'cemü'l-mü'ellifin, 5/218.

201 Bursalı Mehmed Tâhir, Osmanlı Müellifleri, 1/438.

202 Hüseyin Elmalı, "Oflu Mehmed Emin Efendi”, Türkiye Diyanet Vakfi İslâm Ansiklopedisi (Ankara: TDV Yayınlar1, 2019), EK-2/221.

203 Kehhâle, Mu 'cemü'l-mü'ellifin, 9/36. 
10. Musa Kazım Efendi (ö. 1338/1920), İslâm'da cihad.

11. Hacı Hamid Efendi (ö. 1931), Risâle-i İrşâdiye: Dinî, vatanî, askerî. ${ }^{204}$

12. Hasan Fehmi Efendi (ö. 1933), Cihad Hakkında Ehl-i İslâm'a Asker-i İslâm 'a Kürsi-i İslâm'dan Bir Hitap. ${ }^{205}$

13. Osman Senai Erdemgil (ö. 1944), Fezâilü'l-mücahidîn. ${ }^{206}$

14. Çubukçuzâde Mehmed Sıdkı, Sâlâ-yı cihâd.

15. Hacı İzzet Efendi, Mevâizü'l-cihâd ve'd-din li-asâkiri'l-muvâhhidîn.

16. Hamzâ b. Ataullâh, Risale fi fezâili'l-cihâd.

17. Hanyalı Ahmed Efendi, Tahrîsü'l-mücâhidîn.

18. Manisali Hilmi Efendi, Cihadda İslam'ın Vazifesi.

19. Mehmed Hâlid, Risale-i cihâd. ${ }^{207}$

20. Mehmed Hatip Efendi, Fezâil-i remy.

21. Varnalı Süleyman Vehbi Efendi, Risâle-i Fezâ'ilüll-Gâzî ve'ş-Şühedâ fîTafsîl-i Beyân-i Hasâ 'isi'l-Gazâa. ${ }^{208}$

22. Zâgrevî, Mahmud b. İskender b. Abdullah er-Rûmî, Risâle-i sefer ve cihâd-ı ekber

204 Bursalı Mehmed Tâhir, “Fezâîl-i Cihâd Hakkında Müellefât-ı Osmâniyye”, 164.

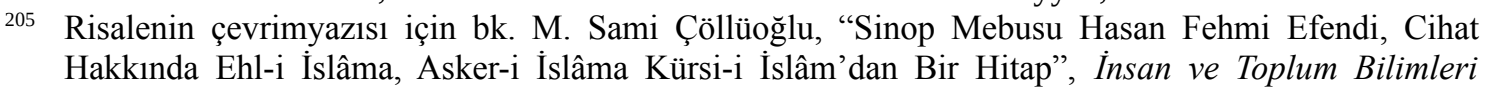
Araştırmaları Dergisi 3/1 (2014), 149-164. Gazâ (y.y.: İstanbul Üniversitesi Nadir Eserler Kütüphanesi, Türkçe Yazma, 297.8), 1a-44b. 


\section{Değerlendirme ve Sonuç}

Hadis kaynaklarında cihad hakkında rivayet edilen hadisler Kitâbü'l-cihâd, Kitâbü'l-megâzî, Kitâbü's-siyer, el-Hayl, Fâzlü'l-cihâd, er-Rimâye ve's-siham temel başlıkları altında ele alınmaktadır. Cihad hakkındaki hadisleri derleme, tasnif etme ve yer yer onlar hakkında kısa açıklamalarda bulunma gibi bir mahiyete sahip bu eserlerin temel hedefleri arasında, Müslümanları gerek mallarıyla gerekse canlarıyla Allah yolunda mücadele etmeye teşfik etme ve bu uğurda onları her türlü hazırlığa müsait hale getirecek örneklikleri sunma sayılabilir.

F1kıh kitaplarında ise cihad ahkâmı Kitâbü'l-cihâd, Kitâbü's-siyer ve Fâzlü'lcihâd gibi bölüm başlıkları altında ele alınmaktadır. Bu eserlerde cihadın fazileti, hükmü, çeşitleri, aşamaları, yasakları, taktikleri ve sonuçları (şehitlik ve gazilik, ganimet ve taksimi, müste'men ve zımmilere dair hükümler) gibi hususlar detaylı bir şekilde incelenmektedir. Söz konusu eserlerin içeriğine bakıldığında ise düşmanla fiili savaşın ön plana çıktığı görülmektedir.

Cihad meselesi mezheplerin temel fürû fikıh eserlerinde muhtelif kitap başlıkları altında incelenmiştir. Hanefî̀ ve Şâfiî mezheplerinin temel kaynaklarında cihad ahkâmı genellikle Kitâbü's-siyer başlığı altında ele alınmış, tasnif bakımından ise konuya çoğunlukla hadlerden sonra yer verilmiştir. Konuya burada yer verilmesinin sebebi olarak, cihad ahkâmının bir yönüyle devletler hukukunun muhtelif meseleleriyle irtibatlı olmasından ötürü iç hukuktan (hâdler) dış hukuka (cihad) bir açılım şeklinde tezahür ettiği zikredilebilir. ${ }^{209}$ Başka bir ifadeyle iç hukukun tükendiği andan itibaren diş hukuka bir açılım olarak cihad meselesinin devreye girmesidir. Nitekim Karâfî, özellikle Şâfî̀’lerin cihad ahkâmını cinayet bahisleriyle birlikte işlemelerini, küfürlerinden ötürü kâfirlere ceza mesabesinde olmasından kaynaklandığını ifade etmektedir. ${ }^{210} \mathrm{Bu}$ duruma

\footnotetext{
209 İslâm dini, tüm insanlara yönelik misyonuyla kendisi dışında kalan kesim (iç-dış gayrimüslim kişi ve devletler) ile münasebetlerinin yürütülmesi problemiyle karşı karşıya kaldığında bu temas -bunu daha sonra her ne kadar İslâm hukukunun alt dalı olan ve bu konulara hasredilen es-siyer teknik terimi altında tartışılmışsa da- cihad ve hükümleri ile ilgili konular üzerinden sağlamıştır. Bk. Macîd Haddûrî, İslâm Hukukunda Savaş ve Barış, trc. Fethi Gedikli (İstanbul: Ekin Yayınları, 2018), 53-59. Karâfî, ez-Zahîire, 2/383.
} 
cihadın ceza hukukuyla irtibatı açısından bakıldığında onun fonksiyonunun iç hukuktan dış hukuka bir açılım şeklinde tezahür ettiği söylenebilir. Yine cihad ahkâmının ele alındığı bölüme bu ismin verilmesinin bir başka sebebi olarak, söz konusu hükümlerin Hz. Peygamber'in hayatından (siyer) alınmış olmasının da etkili olduğu zikredilebilir. ${ }^{211}$ Mâlikî ve Hanbelî mezhep fürû fikıh literatürlerinde ise Kitâbü'l-cihâd başlığı belirgin bir şekilde öne çıkmaktadır. Her iki mezhep tasnif bakımından konuyu ibadetlerle birlikte ele almaktadırlar. Bu mezhep âlimlerinin daha çok cihadın ibadet boyutunu öne çıkarttıkları gözlemlenmektedir. Nitekim Karâfî, Mâlikîlerin böyle bir tercihte bulunmalarının temel sebebinin, Hz. Peygamberin cihadın faziletini anlatan, "Kimin ayağı Allah yolunda tozlanırsa Allah ona cehennem ateşini haram kılar"212 hadisi olduğunu ifade etmektedir. ${ }^{213}$ Zahirî mezhebi ise cihad meselesini Kitâbü'l-cihâd başlı̆̆ 1 altında incelemekte ve tasnif bakımından konuya ibadetlerden (Kitâbü'l-hac) sonra değinmektedir. Bu mezhebin de cihadın ibadet boyutunu öne çıkarttığı söylenebilir.

Cihad literatürünün ilk nüveleri hicri ikinci asrın ortalarında itibaren gün yüzüne çıkmaya başlamıştır. Bunlardan ilki Abdullah b. Mübârek'in (ö. 181/797) cihadın faziletini anlatan Kitâbü'l-cihâd başlıklı hadis derlemesidir. İbn Mübârek ile hemen hemen aynı dönemde yaşamış İmam Muhammed'in (ö. 189/805) es-Siyerü’s-să̆̂̂r ve es-Siyerü'l-kebîr kitapları da -ki bu iki kitap el-Asl adlı eserinin birer bölümünü teşkil eder- cihad ahkâmını detaylı bir şekilde fikhî açıdan konu edinen ilk eserler arasındadır. Bunları müteakiben cihad alanında yazılan müstakil çalışmalar-cihad meselesi klasik hadis eserleri ile fikıh eserleri içinde her dönem zaten incelenmiştir- gün geçtikte artmış ve günümüze kadar konu etrafında zengin bir literatür ortaya çıkmıştır.

Bu literatür etrafında ortaya çıkan eserlerde, cihad ahkâmı incelenirken konular genel olarak âyet ve hadislerle desteklenerek cihadın fâzileti, şekli, türleri, bu hususta göz önünde bulundurulması gereken ilke ve kurallar zikredilir. Osmanlı devleti ağırlıkta olmak üzere son dönemde yazılan eserlerde, ilk nesillerden örnek uygulama ve kâvillere de yer verildiği görülür. Eserlerin yazımında da ilk dönemlerde fetih ve tebliğ ruhu daha

211 Cüveynî, Nihâyetu'l-mațlab, 17/389.

212 Buhârî, el-Câmi 'u'ș-șahîhh, "Cihâd”, 16 (No. 2811).

213 Karâfî, ez-Zahîre, 2/383. 
çok hâkimken modern dönemle birlikte -fetih ve tebliğ de bulunmakla birlikte-bu durum daha çok savunma, nefse karşı mücadele ve bir iç hukuk mücahadesi şekline evrilmiştir.

Aşağıda, hicri ikinci asırdan yirminci yüzyılın ortalarına kadar cihad alanında yazılmış kitap ve risalelerin yüzyıllara, ${ }^{214}$ bölgelere ve mezheplere göre dağılımları üç grafik halinde sunulacak ve grafikler ulaşılan bulgular doğrultusunda değerlendirmeye tabi tutulacaktır.

Grafik 1: Yüzyıllara Göre Cihad Yazımı ${ }^{215}$

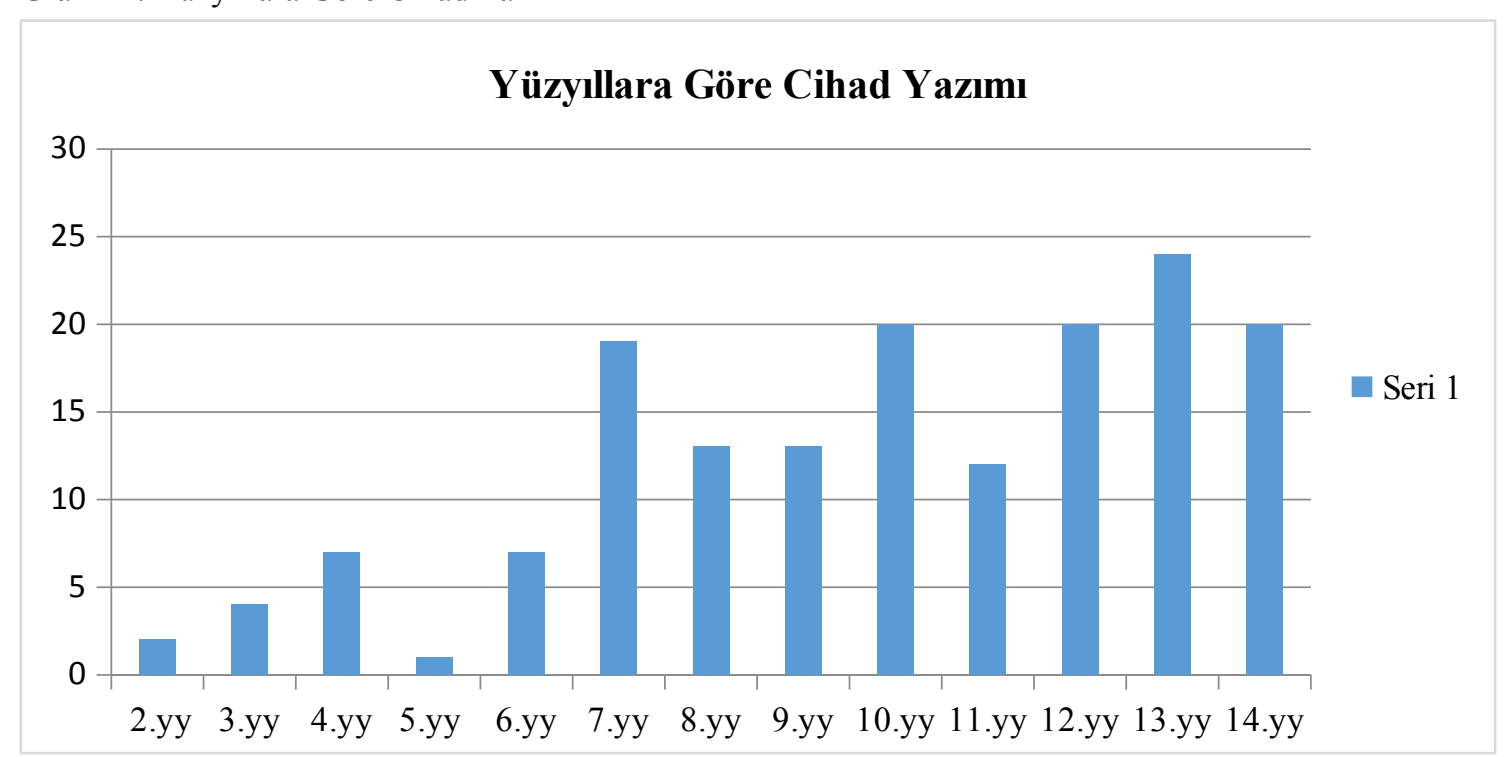

İnsanlık tarihine bakıldığında savaşların yoğunlukta olduğu dönemler ve ondan sonraki süreçler, savaş ile ilgili edebiyatın kemiyet ve keyfiyetinde hareketliliklerin yaşandığı dönüm noktaları olmuştur. Grafiğe bakıldığında İslâm dünyası için de söz konusu durumun örneklerini görebilmekteyiz. Nitekim Haçlı seferlerinin ve Moğol istilâlarının yoğunlukta olduğu hicri yedinci yüzyıl, Osmanlı Devleti'nin duraklama ve gerilime dönemlerine denk gelen on birinci yüzyılın sonu ile on ikinci yüzyıl, devletin

214 Yukarıda ifade edildiği gibi makalede eserler, öncellikle ölüm tarihi tespit edilen müelliflerin ölüm tarihleri göz önünde bulundurularak kronolojik bir şekilde listelenmiştir. Cihad yazımının yüzyıllara göre dağllımını gösteren grafikte yüzyılların belirlenmesinde müelliflerin hicri takvime göre ölüm tarihi esas alınmış ve grafik üzerine yapılan değerlendirmelerde de bu takvim göz önünde bulundurulmuştur.

215 Grafikte on dördüncü yüzyıla ait verilen eserler hicri olarak bütün bir yüzyılı kuşatmayıp ikinci dünya savaşının başlarına kadar yazılan eserleri içermektedir. Bundan sonra verilecek bölge ve mezheplere göre cihad yazımı grafiklerinde de bu durum söz konusudur. 
yıkılma evresine geçtiği on üçüncü yüzyıl ve nihai olarak İkinci Dünya Savaş’1 ile neticelenen on dördüncü yüzyılın ilk yarısı cihad alanında yazılan eser sayısının fazla olduğu dönemler olarak görülmektedir. Aynı şekilde Müslümanların çoğunun yaşadığı Osmanlı Devleti'nin yükselme evresinin sonları ile duraklama döneminin hemen öncesine tekabül eden onuncu yüzyıl da cihad yazımının fazla olduğu bir zaman aralığıdır. Nitekim söz konusu süreçte de cihad alanında yazılan eserlerde görülen fazlalığın temel etmenin fetih ve savaşlardan kaynaklandığı söylenebilir. Gerek Müslümanlar için gerek dünya tarihi için çok hassas dönemler olarak ifade edebileceğimiz bu yüzyıllarda Müslüman âlimleri bu konuda eser yazmaya iten temel saiklerin; Müslümanları ve yöneticilerini ${ }^{216}$ savaşa teşvik etmek, onları zihnen ve bedenen savaşa hazır hale getirmek yeri ve zamanı geldiğinde canlarını ve mallarını bu uğurda feda etmelerine hazırlamak olduğunu ifade edebiliriz.

Grafikte beşinci yüzyılda cihad yazımında gözle görülür bir azalmanın meydana geldiği görülmektedir. Söz konusu dönem Abbâsîlerin siyasî çalkantılar yaşadığı, siyasî güven ve istikrarın azaldığı bir çağdır. Buna mukabil aynı zamanda fikrî bir sıçramanın yaşandığ1, felsefî gündem ve tartışmaların yoğunlaştığı ve kelamî meselelerin daha canlı bir şekilde tartışıldığ 1 bir zaman aralığıdır. ${ }^{217}$ Mevzu bahis gündemlerden ötürü cihad mefhumunun âlimlerin gündeminde daha arka planda kaldığ 1 düşüncesi akla gelmekle birlikte, o dönemde Mâverdî ve Cüveynî gibi âlimlerin el-Ahkâmü's-sultaniyye türünde

216 Biyobibliyografik eserlere müracaat edildiğinde cihad alanında yazılan birçok eserin muhtelif devlet idarecilerine ithaf edildiğini görebilmekteyiz. Örneğin, İbn Cehbel (ö. 596/1200), Fezâilü'l-cihâd eserini Nurettin Zengî için (bk. Kâtip Çelebî, Keşfü'z-zunûn, 2/1275; Bağdatlı İsmail Paşa, Hediyyetü'l- 'ârifin, 1/430); el-Herevî (ö. 611/1215), et-Tezkkiretü'l-hereviyye fi'l-hiyeli'l-harbiyye eserini el-Melikü'z-Zâhir Gāzî için (bk. Bağdatlı İsmail Paşa, Hediyyetü'l-'ârifin, 1/705); İbn Karatekin (ö. 647'den sonra ) Süblü'r-reşad fí fâzli'l-cihâd eserini Melik Necmeddin Eyyûbî için (bk. Kâtip Çelebî, Keş̧ü'z-z̧unûn, 2/978; Bağdatlı İsmail Paşa, Hediyyetü'l- 'ârifin, 2/425); İbn Kesir (ö. 774/1373) el-íctihâd fì tâlebi'l-cihâd eserini İyas kalesini kuşatıldığında Haçlılar'a karşı müslümanları cihada teşvik amacıyla Emir Mencük için (bk. Kâtip Çelebî, Keşfü'z-zunûn, 1/1; Bağdatlı İsmail Paşa, Hediyyetü' 'l- ârifin, 1/215); Molla Arab (ö. 938/1531) es-Sedâd fi fâzli'l-cihâd eserini Sultan Selim'i cihadda kararlı kılmak için (bk. Kâtip Çelebî, Keşfü 'z-zunûn, 2/982; Ömer Rızâ Kehhâle, Mu'cemü'l-mü'ellifin, 11/95); el-Kostendîlî (ö. 1272/1885), Râyâtü'n-nâsr ve'l-irşâd fî fezâili'l-cihâd eserini Sultan Abdülmecit için (bk. Bağdatlı İsmail Paşa, İ̇âhu'l-meknûn, 3/547); Bursalı Mehmed Tâhir, Osmanlı Müellifleri, 1/450) kaleme almıştır.

217 Dönemin siyâsî, fikrî ve kültürel durumunun bir portresi için bk. Muddessir Demir, Mâverdî’nin elAhkâmü's-Sultâniyye’si ile Cüveynî'nin el-Giyâsî̀'sinin Siyâsî-Fıkhî Ahkâm Açısından Mukayesesi (İmâmet Konuları Örneği) (Istanbul: Marmara Üniversitesi, Sosyal Bilimler Enstitüsü, Yüksek Lisans Tezi, 2018), 16-25. 
kaleme aldıkları eserleri cihad konularını da içermekteydi. Söz konusu eserlerde cihad konusu sınırlı bir yer işgal ettiği ve bu eserler münhasıran cihada dair kaleme alınmadıkları için çalışmamızda derlediğimiz eserler arasında bunlara yer verilmemiştir. Böyle bir neticenin çıkmasında mezkûr durumun da bir etkiye sahip olduğu söylenebilir. Nitekim Haddûrî, İslâm'ın entelektüel ve felsefî canlanışına tekabül eden hicri dördüncü ve beşinci yüzyılları, cihad kavramının aktif savaştan uyuyan savaşa kaydığı dönem olarak nitelendirmektedir. $\mathrm{Bu}$ durumun cihad mefhumunda meydana gelen zaaf ve başarısızlıktan kaynaklanmadığı, aksine dönemin sosyal şartlarının ve İslâm'ın çıkarlarının bir neticesi olduğunu ifade etmektedir. ${ }^{218}$

Grafik 2: Bölgelere Göre Cihad Yazımı

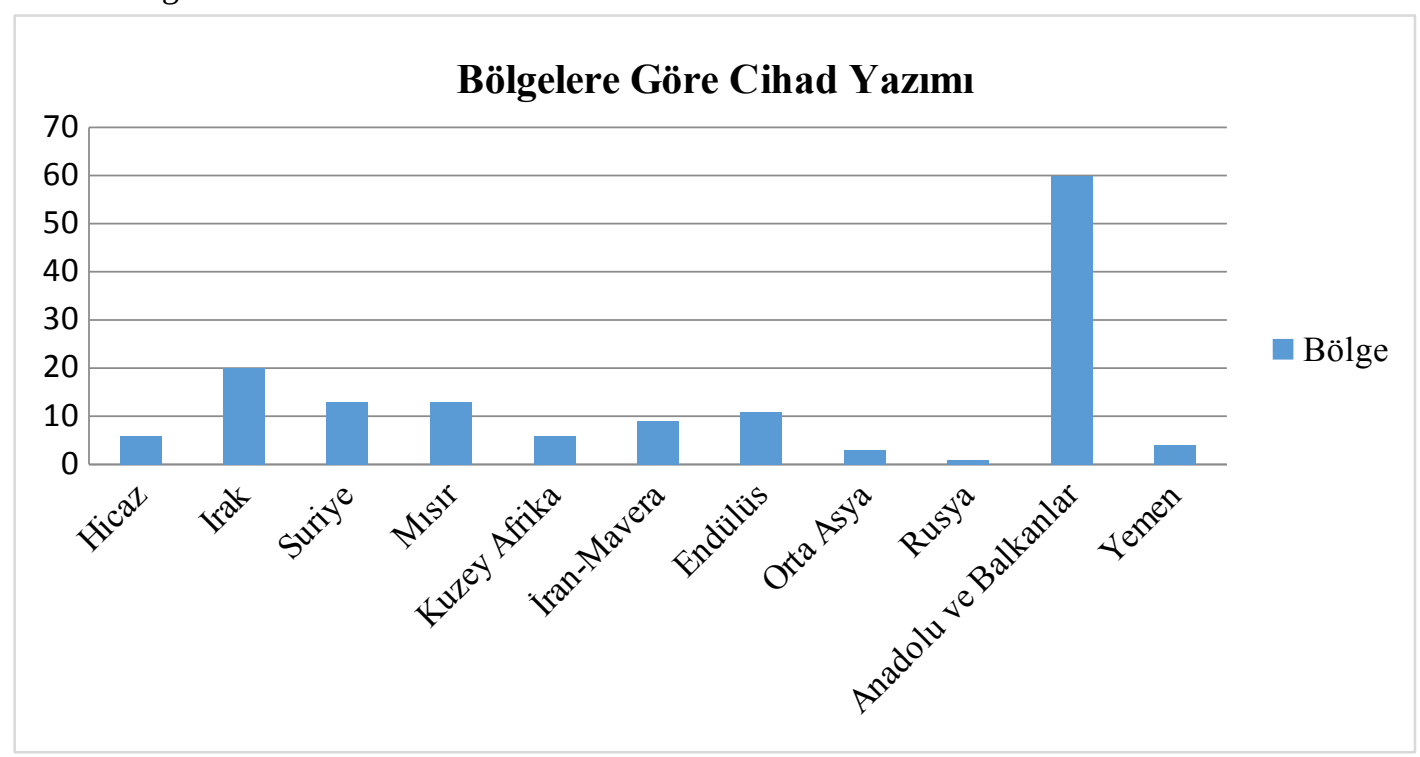

Grafiğe bakıldığında cihad hakkında yazılan eserlerin yoğunlukta olduğu bölgeler sırasıyla Anadolu ve Balkanlar, Irak, Mısır, Suriye ve Endülüs olarak gelmektedir. Mısır, Irak ve Suriye’de kaleme alınan eserlerin sayısının fazla olması yukarıda dile getirildiği gibi bu merkezlerin özellikle Haçlı seferleri ve Moğol istilâlarına karşı verilen mücadelelerde aktif birer konumda olmalarına bağlanabilir. En bariz fark Anadolu ve Balkanlarda görülmektedir. Söz konusu durumun meydana gelmesinde Osmanlı Devleti’nin yaklaşık altı asır boyunca Müslümanların temsilcisi ve hamisi konumunda olması ve devletin bu bölgelerde temerküz etmiş olması gibi 218 Macîd Haddûrî, İslâm Hukukunda Savaş ve Barış, çev. Fethi Gedikli (İstanbul: Ekin Yayınları, 2018), 76-77. 
etkenlerin rol oynadığı söylenebilir. Bununla birlikte bu bölgelerin tarih boyunca Müslümanların kurdukları devletlerin merkezleri ve ilmi faaliyetlerini yoğun olarak gerçekleştirdikleri yerler olmaları böyle bir neticenin doğmasının bir başka önemli etkenleri arasında sayılmalıdır. Cihad alanında yazılan eserlerin kemiyetinde yukarıda zikredilen bölgeler dışında, Rusya bir kenara bırakılırsa geriye kalan diğer bölgeler arasında gözle görülür bir farklılık mevcut değildir.

Grafik 3: Mezheplere Göre Cihad Yazımı

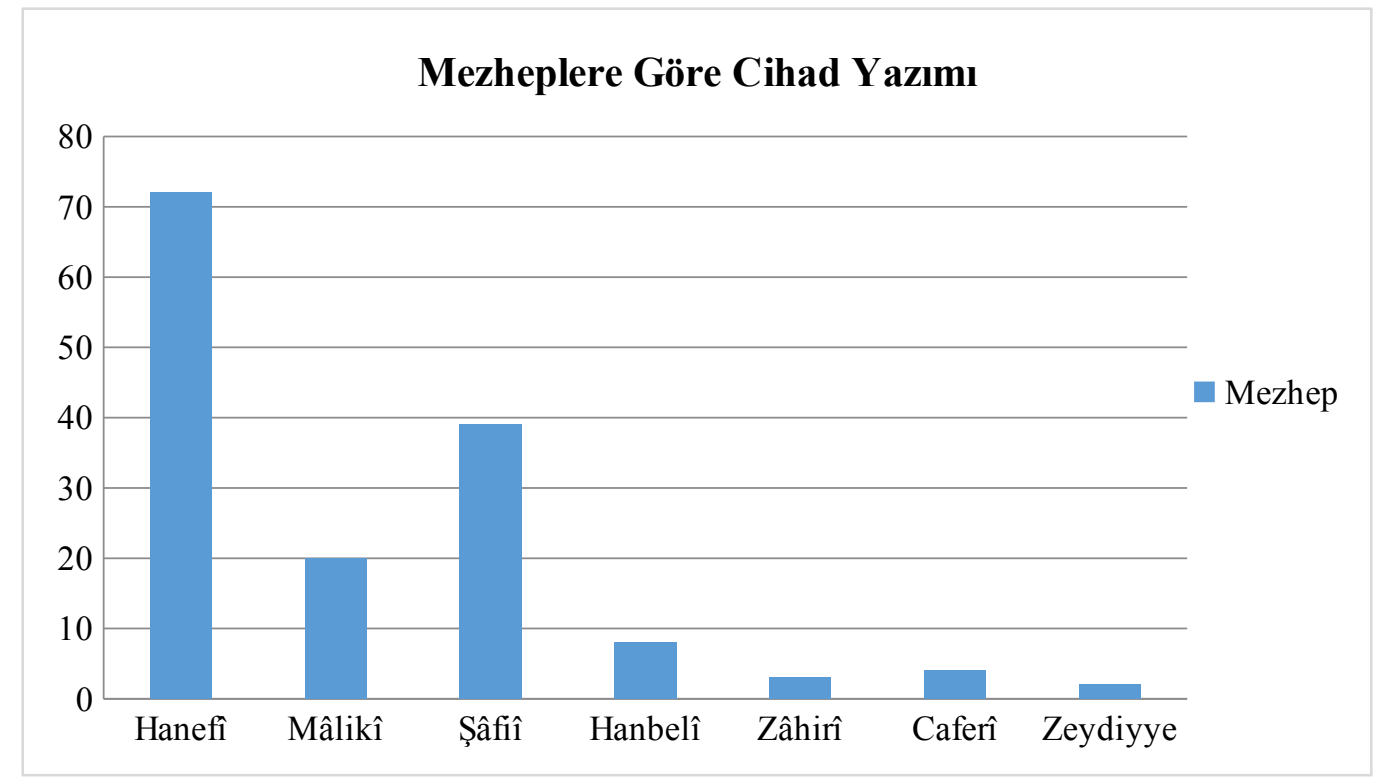

Eserleri kaleme alan müelliflerin müntesip olduğu mezheplere bakıldığında ise en çok ürün verenden en aza doğru Hanefî, Şâfiî, Mâlikî, Hanbelî, Caferî, Zâhirî ve Zeydî şeklinde bir sıralama yapılabilir. Osmanlı Devleti'nin uzun bir süre Müslümanların temsilcisi konumunda olması ve devletin resmi mezhebinin Hanefîlik olması cihad hususunda kaleme alınan eserlerin müelliflerinin büyük yekününün bu mezhebe mensup olma imkânını sağlamıştır. Yine gerek Osmanlı Devletinden önce gerek Osmanlı Devleti ile dönemdaş olan başka birçok devlette Hanefî mezhebine müntesip âlimlerin bürokraside önemli kademelere getirilmesi ve bu mezhebin söz konusu devletlerin bazısında devlet mezhebi olarak kabul edilmesi böyle bir tablonun ortaya çıkmasında etkili olduğu söylenebilir. 
Şâfiî mezhebinin Mısır ve Suriye gibi bölgelerde müntesiplerinin fazla olması, söz konusu bölgelerin İslâm ilim ve düşünce geleneğinin tabiri caizse beşiği mesabesinde olması ve İslâm tarihinin en önemli devletleri arasında sayılan Eyyübî ve Memlük Devletleri’nin bu bölgelerde temerküz edip, Haçlı seferleri ile Moğol istilalarına karşı direnç göstermesi ve bu devletlerde yetişen ilim adamlarının önemli bir kısmının Şâfiî mezhebine müntesip olması gibi hususların Şâfiî mezhebini cihad yazımında etkin kıldığı ve Hanefî mezhebinden sonra ikinci sıraya yükselttiği söylenebilir.

Endülüs ve Kuzey Afrika'nın cihad konusunda en çok eser yazılan bölgeler arasında olması ve bu bölgelerdeki müslümanların tarih boyunca ağırlıklı olarak Mâlikî mezhebine müntesip olması Mâlikîlerin cihad yazımında üçüncü sırada olmalarını anlaşılır kılmaktadır. Yine bu bölgelerde yaşayan Müslümanların bulundukları stratejik konum itibariyle sürekli diğer dinlerle mesai içinde olması da bu durumun ortaya çıkmasına imkân sağlamaktadır.

Cihad sahasında eser ortaya koyan Hanbelî mezhebine müntesib müelliflerin sayıca az olması, mezhep bağlılarının diğer mezhep müntesiplerine göre daha az olması şeklinde yorumlanabilir. Aynı zamanda mezhebin bazı fıkhî ameliye çıkarımında diğer mezheplere nispeten daha sert bir tutum benimsemesi de bu durumun bir başka faktörü olarak zikredilebilir. ${ }^{219}$

Grafikte Caferî mezhebinin diğer mezheplere göre sayıca daha az olması, Şiî bibliyografik ve tabakat eserlerinin detaylı bir taramadan geçirilmemiş olmasından ve araştırmada müracaat edilen kaynakların onlara ait bu kemiyette eser zikretmesinden kaynaklandığı söylenebilir. Aynı zamanda Şî’da cihad ameliyesinin imamın sorumluluğu altında görülmesi, imamın gaybubetinin cihadı mevkuf safhaya geçireceği ${ }^{220}$ ve cihad gibi büyük bir vazifenin de imamın gaybubetten dönmesi ile mümkün olabileceği inancının hâkim olması ${ }^{221}$ söz konusu literatüre bu mezhep müellifleri tarafından çok fazla bir katkının sağlanmamasında rol oynamış olabilir.

219 Haddûrî, İslâm Hukukunda Savaş ve Barış, 48.

220 Zeydîler, kendi imamlarını seçtikleri için bu durum onlar için geçerli değildir.

221 Haddûrî, İslâm Hukukunda Savaş ve Barış, 77-78. 
Zâhirî mezhebinin zaman içinde müntesibinin kalmaması ve mezhebin İslâm toplumunda fazla rağbet görmemesi bu mezhepte cihad konusunda kaleme alınan eserlerin az olmasının sebepleri arasında zikredilebilir.

Bütün bu veriler cihadın tarih boyunca Müslümanlar için çok önemli bir ameliye olduğu gerçeğini tekrar ortaya koymakta, cihad meselesi etrafında yüzyıl, dönem ve mezhep farklılıkları ile birlikte zengin bir literatürün meydana geldiğini göstermektedir. Bunun yanı sıra başta Osmanlı olmak üzere diğer İslâm devletlerinde cihad konusunda kaleme alınan kitap ve risalelerin karşılaştırmalı bir okumaya tabi tutulup bir literatür değerlendirilmesinin yapılmasının söz konusu alanda önemli bir boşluğu dolduracağı kanaatindeyiz. 


\section{Kaynakça}

Âkâle, Âsım Mustafa, Yusuf Ahmed Beni Yasin. “Kitâbü'l-Cihâd li’s-Sülemî: Dîrâsâtün fî̀ Mesâdirihi ve Menhecihi ve Rü’yetihi li's-Sirâi'l-İslâmî-el-Frencî'l-Sâlîbî”. el- 'Ulumu'l-İnsâniye ve'l-İctima 'iye 41/3 (2014), 929-945.

Akpınar, Cemil. "Hanîf İbrahim Efendi”. Türkiye Diyanet Vakfi İslâm Ansiklopedisi. 16/39-42. İstanbul: TDV Yayınları, 1997.

Akpınar, Ömer Faruk. “İslam Edebiyatında Kitâbü’l-Cihâdların Muhteva Gelişimi”. Savaş ve Edebiyat. ed. Yılmaz Daşcıŏlu. 3/255-283. Sakarya: Sakarya Üniversitesi Basımevi, 2016.

Aynî, Ebû Muhammed (Ebü's-Senâ) Bedrüddîn el-. Minhatü's-sülûk fî şerhi Tuhfetü'lMülûk. thk. Ahmed 'Abdurrezzak el-Kebîsî. 1 Cilt. Kaṭar: Vizâretü'l-Evkāf ve'şŞuûni'l-İslâmiyye, 1. Basım, 1428.

Bağdatlı İsmail Paşa. Hediyyetü'l- 'ârifîn esmâ'ü'l-mü'ellifîn ve âsârü̉'l-mușannifîn. thk. Avni Aktuç vd. 2 Cilt. İstanbul: MEB Yayınları, 1955.

Bağdatlı İsmail Paşa. İżâhu'l-meknûn fi'z-żeyli 'alâ Keşfi'z-ẓunûn an esâmi'l-kütüb ve'l-fünûn. thk. Şerefettin Yaltkaya, Kilisli Rifat Bilge. 2 Cilt. Beyrut: Dâru İhyâi't-Türâsi'l-'Arabî, ts.

Bedir, Murtaza. Buhara Hukuk Okulu. İstanbul: İSAM Yayınları, 3. Basım, 2019.

Berzencî, Abdullâh Hasan el-. el-Menhecü's-sedâd ilâ efdâli'l-cihâd. İstanbul: Süleymaniye Kütüphanesi, Laleli, 3680, 61a-74b.

Birinci, Ali. “Kemahlı Şeyh İbrahim Hakkı'nın Serencamı”. Türk Yurdu 110 (1996), 37.

Buhârî, Ebû 'Abdullah Muhammed b. İsmâ' îl b. İbrâhîm el-. el-Câmi 'u'ṣ-ṣaḥ̂hh. thk. Muhammed Zuheyr b. Nâsir. b.y.: Dâru Tavk en-Necât, 1422.

Bursalı Mehmed Tâhir. "Fezâîl-i Cihâd Hakkında Müellefât-1 Osmâniyye" 2-9/46-228 (Kanunisani 1328), 347-348.

Bursalı Mehmed Tâhir. Osmanlı Müellifleri. ed. Fikri Yavuz - İsmail Özen. 3 Cilt. İstanbul: Meral Yayınevi, ts.

Cemel, Suleymân b. 'Ömer b. Mansûr. Hâşsiyetu'l-Cemel 'alâ Şerhi'l-Menhec= Futûhâtu'l-vehhâb bi-tavḍ̂hi Şerhi Menheci't-țllâb. 5 Cilt. Beyrut: Dâru'l-Fikr, ts.

Cevherî, Ebû Nasr İsmâîl b. Hammâd el-. eṣ-Ṣıhâhh fi'l-lugia. thk. Ahmed Abdulgafûr Attâr Attâr. 6 Cilt. Beyrut: Dâru'l-'İlm lil Melâyîn, 4. Basım, 1407.

Cündî, Halîl b. İshâk b. Mûsâ el-. el-Muhtașaru'l-Halil. thk. Ahmed Câd. 1 Cilt. Kâhire: Dâru'l-Hadîs, 1. Basım, 1426. 
Cüveynî, İmâmu'l-Haremeyn el-. Nihâyetu'l-mațlab fì dirâyet'il-mežheb. thk. 'Abdūl 'aẓīm ed-Dīb. Suudi Arabistan: Dâru'l-Minhâc, 1. Basım, 1428.

Çoban, Mehmet. Islâm Hukukunda Cihad Literatürü ve Bedreddin İbn Cemâa'nın Cihadla İlgili Eserlerinin Değerlendirilmesi. İstanbul: Marmara Üniversitesi, Sosyal Bilimler Enstitüsü, Yüksek Lisans Tezi, 2020.

Çolak, Orhan M. "İstanbul Kütüphanelerinde Bulunan Siyasetnâmeler Bibliyografyası". Türkiye Araştırmaları Literatür Dergisi 1/2 (2003), 339-378.

Çöllüoğlu, M. Sami. "Sinop Mebusu Hasan Fehmi Efendi, Cihat Hakkında Ehl-i İslâma, Asker-i İslâma Kürsi-i İslâm'dan Bir Hitap". İnsan ve Toplum Bilimleri Araştırmaları Dergisi 3/1 (2014), 149-164.

Demir, Muddessir. Mâverdî̀nin el-Ahkâmü's-Sultâniyye’si ile Cüveynî'nin elGlyâsî̀sinin Siyâsî-Fıkhî Ahkâm Açısından Mukayesesi (İmâmet Konuları Örneği). Istanbul: Marmara Üniversitesi, Sosyal Bilimler Enstitüsü, Yüksek Lisans Tezi, 2018.

Dursun, Davut. “Günümüz İslâm Dünyası”. Türkiye Diyanet Vakfi İslâm Ansiklopedisi. 23/32-36. İstanbul: TDV Yayınlar1, 2001.

Ebû Ya'lâ el-Mağribî el-Beydâvî. et-Ta'lîkâtü'l-müstazrafe ala Risâleti'l-Mustatrafe. 11 Cilt. b.y.: y.y., ts.

Elbânî, Muhammed Nâsıruddîn. Fihrisü mahtûtâti dâri'l-kütübi'z-zâhiriyye. Riyad: Mektebetü Maârif, 2001.

Elmalı, Hüseyin. "Oflu Mehmed Emin Efendi”. Türkiye Diyanet Vakf İslâm Ansiklopedisi. EK-2/221. Ankara: TDV Yayınları, 2019.

Emanet, Celal. "Haçlı Seferlerinden Önceki Dönemde İslam'da Cihad Düşüncesi”. EKEV Akademi Dergisi 18/60 (Yaz 2014), 503-511.

Ençakar, Orhan. Hanefi Mezhebî Nevâdir literatürü. İstanbul: Marmara Üniversitesi, Sosyal Bilimler Enstitüsü, Doktora Tezi, 2019.

Ferâhîdî, Halîl b. Ahmed el-. Kitâbu'l-'ayn. thk. Mehdî el-Mahzûmî - İbrâhîm elSâmirâî. 8 Cilt. b.y.: Mektebetü'l-Hilâl, ts.

Feyyûmî, Ebü'l-Abbâs Hatîbüddehşe Ahmed b. Muhammed b. Alî el-. el-Mișbâhu'lmünîr fì garîbi'ş-şerhi 'l-keb̂̂r li'r-Râfi î. 2 Cilt. Beyrut: Mektebetü'l-İlmiye, ts.

Firûzâbâdî, Ebü't-Tâhir Mecdüddîn Muhammed b. Ya'kūb b. Muhammed el-. elKāmûsü'l-muhît. thk. Mekteb Tahkiki't-Turâs fi Müeseseti'r-Risâle. 1 Cilt. Beyrut: Müessesetü'r-Risâle, 8. Basım, 1426.

Fuâd Abdülbâkî, Muhammed. el-Mu 'cemü'l-müfehres li-elfâzi'l-Kur'âni'l-Kerîm. 1 Cilt. Kahire: Daru'1 Kütübi'1 Misriyye, 1. Basım, 1364.

Gölcük, Şerafettin. "Bâkıllânı̂”. Türkiye Diyanet Vakfi İslâm Ansiklopedisi. 4/531-535. İstanbul: TDV Yayınları, 1991. 
Gümüşhânevî, Ahmed Ziyâüddîn. "Ensar, Muhacir, Cihâd, Gazve ve Şehitler Hakkında". çev. Ömer Faruk Habergetiren. Tarih Kültür ve Sanat Araştırmaları Dergisi 2/4 (2013), 232-269.

Habeşî, Abdullah Muhammed el-. Mesâdirü'l-fikri'l-İslâmî fi'l-Yemen. Beyrut: elMektebetü el-Asriyye, 1. Basım, 1408.

Haddûrî, Macîd. İslâm Hukukunda Savaş ve Barlş. çev. Fethi Gedikli. İstanbul: Ekin Yayınları, 2018.

Hırakî, Ebü'l-Kâsım Ömer b. Hüseyn b. Abdillâh el-. Muhtaṣaru'l-Hirâḳ̂̂. 1 Cilt. Mısır: Dâru's-Sahâbe li't-Turâs, 1413.

Hüseynî, Muhammed b. İbrahim el-. Zührü'l-mücâhidîn fî âdâb cihâdeddin. İstanbul: Süleymaniye Kütüphanesi, Lala İsmail, 61, 1a-54b.

Iş1k, Mustafa. “İbn Huzeyme”. Türkiye Diyanet Vakfi İslâm Ansiklopedisi. 20/79-81. İstanbul: TDV Yayınları, 1999.

İbn Âbidîn, Muhammed Emîn b. Ömer b. Abdilazîz el-Hüseynî ed-Dımaşkî. Reddü 'lmuhtâr 'ale'd-Dürri'l-muhtâr. 6 Cilt. Beyrut: Dâru'l-Fikr, 2. Basım, 1412.

İbn Arafe, Ebû Abdillâh Muhammed b. Muhammed b. Muhammed b. Arafe elVergammî et-Tûnisî. el-Muhtașar fi'l-fikh. thk. Hâfız Abdurrahman Muhammed Hâyr. 10 Cilt. b.y.: Müesessetü Hâlf Ahmed el-Hâbtûr li'l- A'mâli'l-Hayriyye, 1. Basim, 1435.

İbn Bedrân, Muhammed b. Bedreddin b. Bulbân. Ahșaru'l-muhtașarât fì'l-fikh 'alâ mezhebi'l-imâm Ahmed b. Hanbel. thk. Muhammed Nâsır el-'Acmî. 1 Cilt. Beyrut: Daru'l-Beşa' iri'l-İslamiyye, 1. Basım, 1416.

İbn Hacer el-Askalânî, Ebü'l-Fazl Şihâbüddîn Ahmed b. Alî b. Muhammed. Fethuu'lbârî bi-şerḥi Șaḥ̂hhi’l-Buhârî̀. 13 Cilt. Beyrut: Daru'l-Ma'rife, 1379.

İbn Hazm, Ebû Muhammed 'Alî b. Ahmed b. Saîd. el-Muhallâ bi'l-âsâr fì şerḥi'lMücellâ bi’l-ihtișâr. 12 Cilt. Beyrut: Dâru'l-Fikr, B. y., ts.

İbn Kudâme, Ebû Muhammed Muvaffakuddîn Abdullâh b. Ahmed b. Muhammed. elMuginî. 10 Cilt. Kâhire: Mektebetü'l-Kâhire, B. y., 1388.

İbn Kudâme, Ebû Muhammed Muvaffakuddîn Abdullâh b. Ahmed b. Muhammed. elMukni 'fî fikhi'l-İmâm Ahmed. thk. Mahmud el-Arnavûd - Yasîn Mahmûd elHâtib. 1 Cilt. Cidde: Mektebetü's-Sevâdî li’t-Tevzî‘, 1. Basım, 1421.

İbn Manzûr, Ebü'l-Fazl Cemâlüddîn Muhammed b. Mükerrem b. Alî. 15 Cilt. Beyrut: Daru Sadr, 3. Basım, 1414.

İbn Rüşd, Ebü'l-Velîd Muhammed b. Ahmed b. Muhammed el-Kurtubî. Bidâyetü'lmüctehid ve nihâyetü'l-mukteșıld. 4 Cilt. Kahire: Dâru'l-Hadîs, B. y., 1425.

İbnü'l-İmâd, Ebü'l-Felâh Abdülhay b. Ahmed b. Muhammed el-Hanbelî. Şežerâtü'zżeheb fí ahbâri men żeheb. thk. Mahmûd el-Arnâvûd. 11 Cilt. Beyrut-Dımaşk: Dâru İbn Kesîr, 1. Basım, 1406. 
İmamoğlu, Abdullah Taha. “I. Dünya Savaşı'na Bibliyografik Bir Katkı: Osmanlı'da Cihad Risâleleri”. 100. Yılında Birinci Dünya Savaşı ve Mirası. ed. Halil Çetin Lokman Erdemir. 1/151-179. Çanakkale, 2015.

Kâdîhan, Ebü'l-Mehâsin Fahrüddîn Hasen b. Mansûr b. Mahmûd el-Özcendî el-Fergânî. Terhibü'l-ibâd ile'l-gâzvî ve'l-cihâd. Süleymaniye Kütüphanesi, Fatih, 3481, 1a$45 \mathrm{~b}$.

Karâfî, Ebü'l-Abbâs Şihâbüddîn Ahmed b. İdrîs b. Abdirrahmân el-Misrî el-. ezz-Zahîire. thk. Se'îd A’râb vd. 14 Cilt. Beyrut: Dâru'l-Garbi'l-İslâmî, 1. Basım, 1994.

Kâsânî, Alâüddîn Ebû Bekr b. Mes'ûd b. Ahmed el-. Bedâ'i 'u's-șanâ'i' fì tertibi'şşerâ' 'i'. 7 Cilt. Beyrut: Dâru'l-Kütübi’l-'İlmiyye, 2. Basım, 1406.

Kâtip Çelebî, Hacı Halife Mustafa b. Abdullah. Keşfü'z-zunûn 'an esâmi'l-kütüb ve'lfünûn. 2 Cilt. Ankara: MEB Yayınları, 1941.

Kavak, Özgür. "Fıkıł Literatüründe Cihad Hükümleri ve Modern Cihad Yorumları”. $\dot{I}_{c ̧}$ Tehdit ve Riskler Işı̆̆̆ında İslam Dünyasının Geleceği. ed. Ahmet Emin Dağ. 221-269. İstanbul: İHH Yayınları, 2016.

Kehhâle, Ömer Rıâ. Mu 'cemü'l-mü'ellifîn: Terâcimü mușannifi'l-kütübi'l- 'Arabiyye. 15 Cilt. Beyrut: Mektebetü Mesnâ, ts.

Kızıltunç, Recai. “Arap Edebiyatında Türkçe Yazan Bir Şair: Emir Mencek Paşa elYusûfî". İ. Ü. Şarkiyat Mecmuası 20 (Ocak 2012), 33-48.

Koca, Ferhat. "İbnü’n-Nehhâs ed-Dımaşkî”. Türkiye Diyanet Vakfi İslâm Ansiklopedisi. 21/176-177. İstanbul: TDV Yayınları, 2000.

Köse, Saffet. “İbn Batta”. Türkiye Diyanet Vakfi İslâm Ansiklopedisi. 19/358-359. İstanbul: TDV Yayınları, 1999.

Kudûrî, Ebü'l-Hüseyn Ahmed b. Ebî Bekr Muhammed b. Ahmed el-. el-Muhtașar. thk. Kamil Muhammed Uveyze. 1 Cilt. Beyrut: Daru'l Kütübi'l İlmiyye, 1. Basım, 1418.

Küçük, Raşit. "Abdullah b. Mübârek”. Türkiye Diyanet Vakfi İslâm Ansiklopedisi. 1/122-124. İstanbul: TDV Yayınları, 1988.

Küçük, Raşit. “İbn Ebû Âsım”. Türkiye Diyanet Vakfi İslâm Ansiklopedisi. 19/422-423. İstanbul: TDV Yayınları, 1999.

Maviş, Hakk1. "Mehmed Hâlis Efendi". Türkiye Diyanet Vakfi İslâm Ansiklopedisi. 28/490. Ankara: TDV Yayınları, 2003.

Melikü'l-Efdâl, Necmüddin Eyyûb b. Şazi b. Mervân. Kitâbü'l-cihâd fî sebîlî münşi 'il ibâd. İstanbul: Süleymaniye Kütüphanesi, Ayasofya, 2002, 1a-20b.

Merḡinnânî, Ebü'l-Hasen Burhânüddîn 'Alî b. Ebî Bekr b. 'Abdilcelîl el- - Yusuf, Tallal

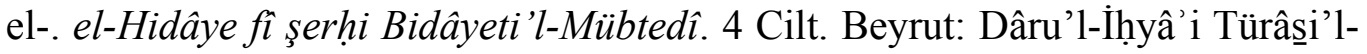
'Arabi, ts. 
Merkezü'l-Melik Faysal. Hizânetü 't-turâs. 125 Cilt. Suudi Arabistan: y.y., ts.

Mevsilî, Ebü'l-Fazl Mecdüddîn 'Abdullāh b. Mahmûd b. Mevdûd el-. el-İhtiyâr li ta 'alili’l-Muhtâr. 5 Cilt. Beyrut: Matba 'atü'l-Halebî, 1356.

Munâvî, Zeynüddîn Muhammed Abdürraûf b. Tâcil'ârifîn b. Nûriddîn Alî el-. et-Tâvkîf 'alâ muhîmâtî̀t-te'ârîf. 1 Cilt. Kahire: Alemü'l-Kütüb, 1. Basım, 1410.

Mutarrizî, Ebü'l-Feth Burhânüddîn Nâsır b. Abdisseyyid b. Alî el-. el-Muǵgrib fî tertîbi'l-Mu 'rib. 1 Cilt. b.y.: Dâru'l-Kitâbi'l-'Arebî, ts.

Müzenî, Ebû İsmâ'îl b. Yaḥyâ İsmâîl el-. Muḥtașaru’l Müzenî. 1 Cilt. Beyrut: Dâru'lMa'rife, 1410.

Nedîm, Ebü’l-Ferec Muhammed b. Ebî Ya'kûb İshâk b. Muhammed b. İshâk en-. elFihrist. thk. İbrahim Ramazan. 1 Cilt. Beyrut: Daru'l-Ma rife, 2. Basım, 1417.

Nesâî, Ebû 'Abdirraḥmân Aḥmed b. Şu'ayb b. 'Alî el-Hुorâsânî en-. es-Sunenul'lkubrâ. thk. Hasan 'Abdulmun'im eş-Şelebî. 12 Cilt. Beyrut: Mü'essesetü'rRisâle, 1. Basım, 1421.

Nevevî, Ebû Zekeriyya Muhyiddîn Yahya b. Şerîf en-. Minhâcu't-ṭ̂libîn ve 'umdetu'lmuttakīn fi'l-fikh. thk. Kāsım Aḥmed 'Avvaḍ. Beyrut: Dâru'l-Fikr, 2005.

Nûreddinzâde, Filipeli Mustafa Muslihuddîn. Fezâilü'l-cihâd. İstanbul: Süleymaniye Kütüphanesi, Ayasofya, 1987.

Önal, Ramazan. Gazzîzâde Abdüllatîf Efendi'nin Fütuhâtu Kenzi'l-Kur'ân Adlı Fâtiha Sûresi Tefsîrinin Tahlili ve Değerlendirilmesi. Bursa: Uludă̆ Üniversitesi, Sosyal Bilimler Enstitüsü, Yüksek Lisans Tezi, 2013.

Özaydın, Abdülkerim Özaydın. "İbn Kesîr”. Türkiye Diyanet Vakfi İslâm Ansiklopedisi. 20/132-134. İstanbul: TDV Yayınları, 1999.

Özcan, Tahsin. "Veliyyüddin Cârullah". Türkiye Diyanet Vakfi İslâm Ansiklopedisi. 43/38-40. Istanbul: TDV Yayınları, 2013.

Özel, Ahmet. “Ayıntâbî”. Türkiye Diyanet Vakfi İslâm Ansiklopedisi. 245-246. İstanbul: TDV Yayınları, 1991.

Özel, Ahmet. "Cihad”. Türkiye Diyanet Vakf İslâm Ansiklopedisi. 7/27-31. İstanbul: TDV Yayınları, 1993.

Özel, Ahmet. Dârülislâm-Dârülharb Harb İslâm Hukukunda Ülke Kavramı. İstanbul: İz Yayıncılık, 3. Basım, 2019.

Özel, Ahmet. "Kirmâstî”. Türkiye Diyanet Vakfi İslâm Ansiklopedisi. 26/67-68. Ankara: TDV Yayınları, 2002.

Râgıb el-İsfahânî, Ebû'l-Ḳāsım Hüseyn b. Muhammed b. er-. el-Müfredât fí garîbi'lKur'ân. thk. Șafvân 'Adnan ed-Dâvûdî. Dımaşk: Daru'l-Kalem-Daru'şŞâmiyye, 1. Basım, 1412. 
Sağırlı, Abdurrahman. Keşfî Mehmet Çelebi Selim-name veya Bağ-ı Firdevs-i Guzat ve Ravza-i Ehl-i Cihad. İstanbul: İstanbul Üniversitesi, Sosyal Bilimler Enstitüsü, Yüksek Lisans Tezi, 1993.

Sahnûn, Ebû Saîd Abdüsselâm b. Saîd b. Habîb et-Tenûhî. el-Müdevvenetü'l-kübrâ. 5 Cilt. Beyrut: Dâru'l-Kütübi'l- 'İlmiyye, 1. Basım, 1415.

Sakkâr, Sâmî es-. "İbn Allân”. Türkiye Diyanet Vakfi İslâm Ansiklopedisi. 19/307-308. İstanbul: TDV Yayınları, 1999.

Sandıkçı, S. Kemal. "Ebû Muhammed İbn Asâkir". Türkiye Diyanet Vakfi İslâm Ansiklopedisi. 19/320-321. İstanbul: TDV Yayınları, 1999.

Semerkandî, Ebûbekir Alâüddîn Muhammed b. Ahmed es-. Tuhfetu'l-fukahā. 3 Cilt. Beyrut: Dâru'l-Kütübi'l- 'Illmiyye, 2. Basım, 1414.

Serahsî, Ebû Bekr Şemsü'l-e'imme Muhammed b. Ebî Sehl Ahmed es-. Şerḥu'ssiyeri'l-kebīr. 5 Cilt. b.y.: eş-Şeriketu'ş-Şarkiyye lil-İ' lānāt, ts.

Serahsî, Muhammed b. Ahmed b. Ebî Sehl Şemsu'l-eimme es-. el-Mebșuṭ. 30 Cilt. Beyrut: Dâru'l-Ma'rife, B. y., 1414.

Severcan, Şefaettin. Keşfi'nin Selimnâmesi. Kayseri: Erciyes Üniversitesi, Sosyal Bilimler Enstitüsü, Yüksek Lisans Tezi, 1988.

Şâfi î, Ebû 'Abdullah Muḥammed b. İdrîs eş-. el-Üm. 8 Cilt. Beyrut: Dâru'l-Ma'rife, 1410.

Şahin, Kürşat Şamil. "Gazavâtnâmeler Üzerine Yapılan Çalışmalar Hakkında Bir Bibliyografya Denemesi”. Turkish Studies 7/2 (2012), 997-1022.

Şeybânî, Ebû Abdillâh Muhammed b. el-Hasen b. Ferkad eş-. es-Siyerü ’s-Ṣağîr. thk. Mecîd Haddûrî. 1 Cilt. Beyrut: ed-Dâru'l-Müttehide, 1. Basım, 1975.

Şimşek, Selami. "Erzincan Mevlevîhânesi Son Postnişîni Kemahlı İbrahim Hakk1 Efendi’nin Dîvân'ında Mevlânâ ve Mevlevîlikle İlgili Düşünceleri”. Tasavvuf: İlmî ve Akademik Araştırma Dergisi 8/20 (2007), 159-174.

Şîrâzî, Cemâluddîn İbrâhim b. 'Alî b. Yûsuf Ebû İshâk eş-. el-Muhezzzeb fî fikhi'l-İmâm eş-Şâfi 'î. 3 Cilt. Beyrut: Dâru'l-Kütübi'l-'İlmiyye, ts.

Tekindağ, M. C. Şehabeddin. "Selimnâmeler”. İstanbul Üniversitesi Edebiyat Fakültesi Tarih Enstitüsü Dergisi 1 (Ekim 1970), 197-230.

Tirmizî, Muhammed b. 'Îsâ b. Sevre b. Mûsa b.ed-Daḥhâk et-. Sünen-i Tirmizî. thk. Aḥmed Muḥammed Şâkir-Muḥammed Fu'âd 'Abdülbâḳ̂̂İlbrâhîm Utve 'Avd. 5 Cilt. Mısır: Şirketü Mektebeti ve Maṭbaati Muștafa el-Bâbî el-Ḥalebî, 2. Basım, 1395.

Türkmen (Çağman), Nihal. Ali Dede Bosnevi Hayatı, Eserleri ve Fezai'lü'l-Cihad Adlı Eseri. İstanbul: Marmara Üniversitesi, Sosyal Bilimler Enstitüsü, Yüksek Lisans Tezi, 2019. 
Uzun, Mustafa İsmet. "Fevzi Efendi”. Türkiye Diyanet Vakfi İslâm Ansiklopedisi. 12/506-509. Ankara: TDV Yayınları, 1995.

Üzüm, İlyas. "Hatibzâde Muhyiddin Efendi”. Türkiye Diyanet Vakfi İslâm Ansiklopedisi. 16/463-464. İstanbul: TDV Yayınları, 1997.

Varnalı Süleyman Vehbi Efendi. Risâle-i Fezâilü'l-Gâzî ve'ş-Şühedâ fî-Tafsîl-i Beyân-i Hasâisi'l-Gazâ. y.y.: İstanbul Üniversitesi Nadir Eserler Kütüphanesi, Türkçe Yazma, 297.8, 1a-44b.

Yaman, Ahmet. "Siyer". Türkiye Diyanet Vakfi Íslâm Ansiklopedisi. 37/316-319. İstanbul: TDV Yayınları, 2009.

Yıldırım, Selahattin. "XIX. Yüzyıl Osmanlı Muhaddisleri ve Eserleri”. Din Eğitimi Araştırmaları Dergisi 13 (2004), 151-182.

Yılmaz, Hakan. "Tarihten Sayfalar: Murâd Hüdâvendigâr Adına Yazılmış Bir Eser: Tuhfetü'l-Guzât fî Fezâ'ili'l-Cihâd”. Hakikat Dergisi 198 (Mart 2010).

Y1lmaz, Hayati. "Nûh b. Mustafa el-Konevî'nin er-Risâle fi'l-Fark Beyne'l-Hadîsi'lKudsî ve'l-Kur'ân ve'l-Hadîsi'n-Nebevî Adlı Risâlesi’. Hadis Tetkikleri Dergisi 1/1 (2003), 167-178.

Y1lmaz, Okan Kadir. Illk Tedvin Döneminde Hanefi Mezhebi Literatürünün Kayıp Eserleri. İstanbul: Marmara Üniversitesi, Sosyal Bilimler Enstitüsü, Yüksek Lisans Tezi, 2017.

Yurdaydın, Hüseyin Gazi. "Matrakçı Nasuh". Türkiye Diyanet Vakfi İslâm Ansiklopedisi. 28/143-145. Ankara: TDV Yayınları, 2003.

Zehebî, Ebû Abdillâh Şemsüddîn Muhammed b. Ahmed b. Osmân ez-. Siyeru a 'lâmi'nnübelâ'. thk. Şu'ayb el-Arnavût. 25 Cilt. b.y.: Müessesetü'r-Risâle, 3. Basım, 1405.

Ziriklî, Ebû Gays Muhammed Hayrüddîn b. Mahmûd b. Muhammed b. Alî b. Fâris ez-. el-A 'lâm. 8 Cilt. b.y.: Dâru'l-İlmi'l-Melâyîn, 15. Basım, 2002. 